\title{
PRVIH 20 GODINA ČASOPISA NATIONAL SECURITY AND THE FUTURE
}

\author{
Miroslav Tuđman*
}

\begin{abstract}
The author gives an overview of the history of National Security and the Future (NSF). The first editorial board accepted a clear vision and mission of the NSF. That is why the NSF had to react to the political circumstances in which the journal has operated for 20 years. In the first period, international circumstances and the policy of detuđmanization directly influenced the choice of topics and papers published in the journal. For the past five years, the NSF has paid particular attention to the security of national and European critical infrastructure. A total of 257 texts were published on more than 8,000 pages and authored by 134 authors from 25 countries. The NSF has published studies on historical forgery, information operations, production of "fake news" and contributions to the theory and methodology of intelligence activities.
\end{abstract}

Ključne riječi: National Security and the Future, misija, povijest, teme, praksa, teorija, nacionalna sigurnost

* Prof. dr. sc. Miroslav Tudjman - Professor of Information Sciences at the University of Zagreb, Faculty of Humanities and Social Sciences (19882016). Deputy Director of the Office for National Security (UNS) and Director of the Croatian Intelligence Service (HIS) from 1993 to 1998, and from 1999 to 2000. Editor-in-Chief of National Security and the Future from 2000. Contributed to various scientific projects, published eighteen books and more than two hundred articles in scientific journals. Editor of more than twenty proceedings. Active in research, both in the field of information science and national security and intelligence. 
Keywords: National Security and the Future, mission, history, main topics, practice, theory, national security

\section{Početak i ambicije}

Na početku 21. stoljeća područje izvještajne djelatnosti bilo je tek fakultativni predmet na sveučilištima u zapadnoj Europi, a u zemljama bivšeg istočnoga bloka izvještajna djelatnost bilo je područje zatvoreno za znanstvenu javnost. Istraživanje "načela i praksa“ izvještajne djelatnosti bili su pod kontrolom izvještajnih službi, kao i edukacija djelatnika izvještajnih službi.

Projekt National Security and the Future (NSF) pokrenut je u veljači 1999. godine, kako bi popunio prazninu prisutnu u srednjoj $\mathrm{i}$ jugoistočnoj Europi, gdje ne postoje nacionalni ili međunarodni časopisi s područja nacionalne sigurnosti. Već u lipnju 2000. godine, objavljen je prvi broj znanstvenog časopisa National Security and the Future.

Časopis je od svog početka bio „posvećen razvoju i razumijevanju načela $\mathrm{i}$ prakse izvještajne djelatnosti $\mathrm{i}$ nacionalne sigurnosti u suvremenoj povijesti i vanjskoj politici“ a namijenjen najširoj javnosti. ${ }^{1}$

Kako je najavljeno u uvodniku prvoga broja NSF je imao višestruke ambicije: istraživati i razumjeti prakse izvještajnih službi i unaprjeđivati teoriju i metodologiju izvještajne djelatnosti; pridonositi razumijevanju i istraživanju fenomena nacionalne sigurnosti. Također, vjerovali smo da NSF treba imati određenu pionirsku i obrazovnu svrhu - otvaranjem prostora za razmatranje ključnih problema nacionalne sigurnosti i izvjesnica u javnostima zemalja srednje i istočne Europe, gdje postoji velika potreba za takvim raspravama. Željeli smo pridonijeti i razvoju novog akademskog studija izvještajne djelatnosti i nacionalne sigurnosti kao posebnog, prepoznatljivog znanstvenog područja.

Po svojim ambicijama NSF bio je od svog početka jedinstven iz više razloga. Prvo, od prvoga broja imao je respektabilno

1 Od prvoga broja u impresumu navedeno je područje kojim se časopis bavi: „National Security and the Future is dedicated to the advancement and understanding of principles and practices of intelligence and national security in contemporary history and foreign policy" 
međunarodno uredništvo: prof. dr. W. Agrell (Švedska), prof. Christopher Andrew (G. Britanija), general Todor Boyadjiev (Bugarska), Oldrich Cerny (Češka Republika), prof. dr. Stevan Dedijer (Švedska, Hrvatska), Richard Kerr (SAD), prof. dr. Janos Matus (Mađarska), Miroslav Međimorec (Hrvatska), general Leonid Shebarshin (Rusija), Richard Stolz (SAD) i prof. dr. Miroslav Tuđman (Hrvatska). ${ }^{2}$

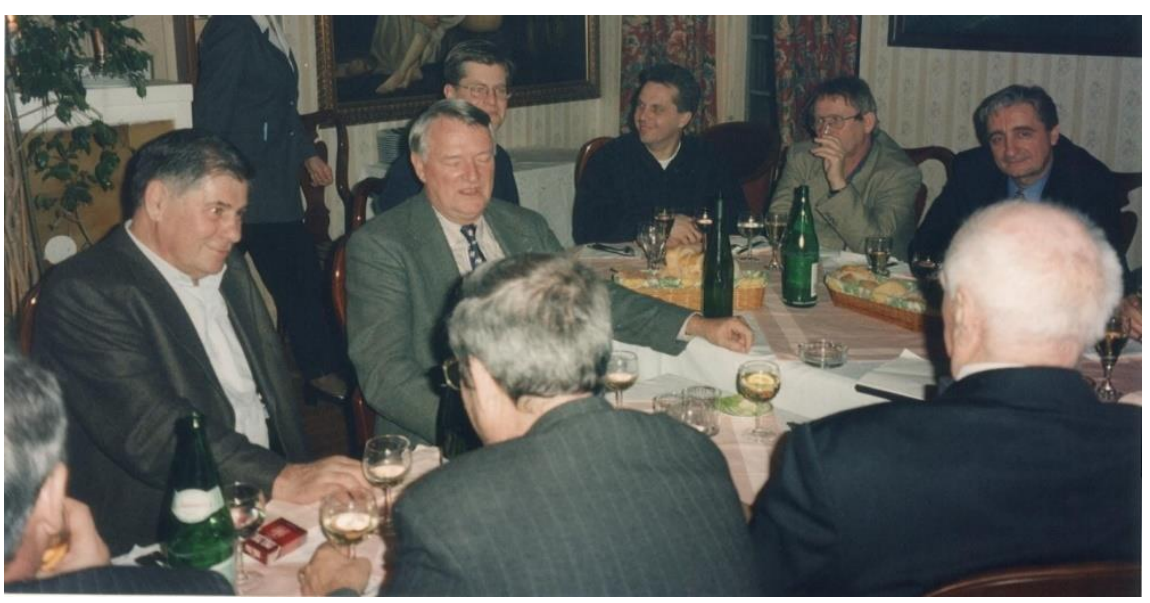

Prvi sastanak uredništva, Dubrovnik 26. i 27. veljače 1999.

Drugo, uredništvo je bilo posebno jer je već na samome svom početku uspjelo okupiti ne samo ugledne znanstvenike iz SAD i Europe, već i bivše ravnatelje ili zamjenike ravnatelja službi: general Todor Boyadjiev (ministarstvo unutarnjih poslova, Bugarska), Richard Kerr i Richard Stolz (CIA, SAD), general Leonid Shebarshin (KGB, SSSR), Oldrich Černy (Češka izvještajna služba), Miroslav Međimorec (SIS, Hrvatska). U uredništvo NSF-a tijekom godina kooptirani su i Drago Ferš (bivši direktor SOVA, Slovenija), admiral Pierre Lacoste (bivši direktor DGSE, Francuska), Nikolai Leonov (zamjenik direktora KGB, SSSR), Doug Smith (CIA, SAD), admiral Davor Domazet Lošo (načenik Ob. uprave HV, Hrvatska). Treće, glavni urednici prvih brojeva bili su prof. dr. Janos Matus (Zrinyi Miklos National Defence University, Mađarska) i prof. dr. Miroslav Tuđman (Filozofski fakultet, Zagreb). Četvrto, tekstovi su tiskani na engleskom (i 
hrvatskom) jeziku kako bi bili dostupni i međunarodnoj javnosti.

Prvi je sastanak uredništva NSF-a održan u Dubrovniku, veljače 1999. godine, gdje se raspravljalo o uređivačkoj politici NSF. O tome su u Dubrovniku po prvi puta 1999. za istim stolom zajedno sjedili i razgovarali bivši zamjenici direktora CIA-a R. Kerr i R. Stolz te KGB-a L. Shebarshin koji su koncem 1980-ih bila na vodećim pozicijama u svojim službama, službama koje su desetljećima međusobno ratovale. I onda je to bila svojevrsna senzacija. Neponovljiva. Ne samo zato što dio urednika NSF iz toga vremena više nije živ, nego i zato što su se političke okolnosti promijenile. Ne samo politički odnosi između SAD-a i Putinove ZND-a, nego i zato što je Hrvatska prokockala svoju šansu iz 1999. kada je imala ugleda, snage i znanja okupiti na projektu NSF najuglednije znanstvenike i umirovljene šefove najvećih izvještajnih službi.

Zašto je bilo moguće u Hrvatskoj pokrenuti prvi međunarodni znanstveni časopis iz područje izvještajne djelatnosti i nacionalne sigurnosti u srednjoj i istočnoj Europi, s uredništvom znanstvenika i bivših ravnatelja izvještajnih službi s dugom tradicijom međusobnih obračuna? Jamačno je tome išlo u prilog uvjerenje, koje je vladalo 1990-ih godina, da se s padom berlinskoga zida i raspuštanjem Varšavskoga pakta Europa nepovratno riješila blokovske podjele svijeta i komunističkoga poretka; te da je radi prevladavanja preostalog komunističkoga nasljeđa i mentaliteta bila nužna suradnja i u istraživanju nacionalne i europske sigurnosti.

U takvim međunarodnim okolnostima hrvatska inicijativa za pokretanje NSF-a bila je prepoznata, prihvatljiva i logična iz niza razloga. Sve su europske države s komunističkim pedigreom imale nenasilnu transformaciju u demokratski politički sustav, jer su višenacionalne SSSR i Čehoslovačka prihvatile mirnu transformaciju svojih federalnih sastavnica $u$ nacionalne države. Tome nasuprot, Hrvatska se u nametnutome ratu morala politički, diplomatski i vojno izboriti za svoju neovisnost i teritorijalnu cjelovitost, a u tim su povijesnim promjenama hrvatske izvještajne službe odigrale važnu ulogu.

Jednako kao i svoju diplomaciju i oružanu silu Hrvatska je morala formirati svoje izvještajne službe koje nisu postojale prije neovisnosti. Hrvatska izvještajna služba (HIS), vojna Sigurnosno informativna služba (SIS), Obavještajna uprava Glavnog stožera HV nisu postojale prije 1990-ih, niti su bile sljednice bilo koje jugoslavenske službe. Izuzetak je Služba 
za zaštitu ustavnoga poretka (SZUP), koja je bila sljednica SDS-a.

Pod konac 1992. sazrjela je odluka o formiranju Obavještajne zajednice $\mathrm{RH}$ koju su činile sve izvještajne i sigurnosne službe. Od samoga početka HIS je imao ključnu ulogu u koordinaciji planova i operacija hrvatskih izvještajnih službi, ali isto tako i u koordinaciji suradnje sa stranim izvještajnim i protuizvještajnim službama.

Velikosrpskom agresijom na $\mathrm{RH}$ i $\mathrm{BiH}$ započeo je rat na području Europe, prvi rat nakon drugoga svjetskog rata. Zato je suradnja izvještajnih službi s ciljem prikupljanja i razmjene izvjesnica te pripreme preciznih izvještajnih prosudbi bila prva pretpostavka za politiku uspostave mira i sigurne budućnosti Europe. Zbog hrvatske državne politike koja je bila zainteresirana za internacionalizaciju krize Obavještajna zajednica RH našla se u središtu interesa stranih službi, pa je postala poželjan partner velikom broju izvještajnih službi - ne samo zemalja koje su bile najangažiranije u predlaganju mirovnih planova, nego i susjednih država te posredno zainteresiranih država.

U kratkom su razdoblju hrvatske izvještajne službe uspostavile suradnju i partnerske odnose s nizom izvještajnih službi u Europi i svijetu - od razmjene informacija do zajedničkih operacija. HIS je kao vanjska služba bio nadležan za suradnju sa stranim partnerima. Ta je suradnja bila vrlo intenzivna svo vrijeme agresije tadašnje SRJ (Srbije i Crne Gore) i trajanja rata u $\mathrm{RH}$ i $\mathrm{BiH}$. Suradnja je poprimala različite organizacijske forme u prikupljanju informacija, te pripremi izvještajnih procjena političkih ciljeva i vojnih planova sukobljenih strana u ratu i ratovima na području bivše Jugoslavije.

O toj suradnji mogu osobno svjedočiti, jer mi je $u$ to vrijeme bila dužnost uspostavljati odnose i održavati susrete s čelnicima izvještajnih službi, te sudjelovati u izvještajnim procjenama i procjenama mogućih scenarija za rješavanje postojećih sukoba. ${ }^{3}$ Što su partnerske izvještajne službe mislile o radu i uspjehu hrvatskih izvještajnih službi, slikovito govori njihova reakcija nakon što smo ih u ponoć ili ujutro 4. kolovoza 1995., izvijestili o ciljevima i vremenu trajanja vojno redarstvene operacije Oluja: tri dana glavne operacije i tri dana rješavanja zaostalih džepova. Nakon šest dana, počeo 1993. do svibnja 1998., te od srpnja 1999. do 15. veljače 2000. 
sam primati čestitke i doslovno sanduke šampanjca od časnika za vezu kao priznanje za točne izvještajne procjene te za uspješno obavljenu vojno-redarstvenu operaciju.

Ugled što ga su ga hrvatske izvještajne službe stekle tijekom ratnih godina i na poslovima mirne reintegracije hrvatskoga Podunavlja, te osobni kontaktni koje sam imao, bili su onaj „kapital“ na kojem je bilo moguće okupiti međunarodno uredništvo NSF-a. Očito da ljudi koji su obnašali tako visoke dužnosti u sustavima nacionalne sigurnosti ne bi prihvatili sudjelovati u uredništvu NSF da i sami nisu bili uvjereni u opravdanost i svrhovitost samog projekta i ugled hrvatskih službi; no, za pretpostaviti je da su za to dobili i zeleno svjetlo od svojih institucija.

Nakon završetka mirne integracije hrvatskoga Podunavlja, u proljeće 1998., na vlastiti zahtjev, razriješen sam dužnosti zamjenika predstojnika UNS-a i ravnatelja HIS-a. Vratio sam se na Filozofski fakultet te sam mogao tijekom 1998. započeti dogovore o uredništvu NSF. ${ }^{4}$ Prvi je sastanak uredništva održan već u veljači 1999., a prvi broj časopisa tiskan je u lipnju 2000. godine. ${ }^{5}$

\section{Promocija prvoga broja}

Predsjednik Republike Italije Francesco Cossiga bio je prvi je strani državnik koji je posjetio međunarodno priznatu Republiku Hrvatsku. ${ }^{6}$ Senator Francesco Cossiga bio je i gost urednik prvoga broja NSF-a objavljenog u lipnju 2000. godine. Prvi broj NSF-a bio je posvećen aktualnim temama: NATOvoj intervenciji na Kosovu (J. Tarin, T. Batkovski) i krizama na jugoistoku Europe (P. Pantev, K. Ćosić, S. Domljanović).

4 Kao profesor na Filozofskom fakultetu ostao sam vezan i uz izvještajni sustav kao predsjednik Vijeća Obavještajne akademije UNS-a koja je osnovana 1998. godine. Za predsjednika Vijeća Obavještajne akademije UNS-a imenovan sam 1. listopada1998. godine.

5 Nekoliko je razloga zašto je prvi broj NSF-a tiskan tek sredinom 2000. godine. Prvi je što sam u srpnju 1999. ponovo preuzeo dužnost zamjenika predstojnika UNS-a i ravnatelja HIS-a na kojoj sam ostao sve do 15. veljače 2000. kada sam dao ostavku. Nakon smrti predsjednika F. Tuđmana (10. prosinca 1999.) održani su početkom 2000. godine parlamentarni i predsjednički izbori na kojima je pobijedila koalicija na čelu s reformiranim komunistima. Dakle, osobni i politički razlozi imali su za posljedicu da je NSF tiskan s godinu dana „zakašnjenja“.

6 Francesco Cossiga (1928. - 2010.) bio je ministar unutarnjih poslova (1976.-1978.), predsjednik talijanske vlade (1979.-1980.), predsjednik talijanskog Senata (1983.-1985.), talijanski predsjednik (1985.-1992.), a 1992. proglašen je doživotnim senatorom. 
O izvještajnoj djelatnosti u 21. stoljeću pisali su bivši zamjenik direktora KGB-a L. V. Shebarshin i analitičarka CIA-e H. L. Boatner.

Studije slučajeva obrađene u prvom broju aktualne su istraživačima i danas: izvještajne procjene SAD-a (19481991) o Jugoslaviji (J. Baev); rat u Bosni i Hercegovini (D. Domazet-Lošo, D. Marijan). Članak ruskog generala A. Liakhovsky-og o građanskom ratu u Afganistanu bio je i ostao najposjećeniji članak na web stranicama NSF-a.

Promocija prvoga broja NSF-a održana je 7. lipnja 2000. godine $u$ atriju Nacionalne i sveučilišne knjižnice. $U$ ime uredništva na promociji sam rekao i sljedeće:

Motivi za pokretanje časopisa su brojni. Hrvatska je u kratkom vremenu morala uspostaviti mehanizme $i$ instrumente svoje nacionalne sigurnosti kao pretpostavku svoje budućnosti. Učeći od drugih, surađujući s drugima - i

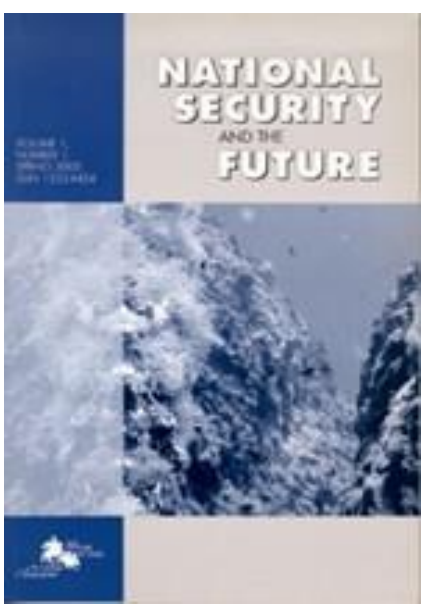
želeći svoja iskustva dijeliti s drugima - došlo je vrijeme evaluacije ne samo hrvatskih iskustava (ona mogu poslužiti kao razuman povod) već isto tako iskustava svih zemalja u tranziciji, ali $i$ djelotvornosti instrumenata $i$ mehanizama međunarodne sigurnosti.

... Zbog brzine povijesnih promjena, vjerojatno kao nikada prije, područje nacionalne sigurnosti objedinjuje predmete bavljenja povijesti, političke znanosti ali i obavještajnih zajednica. Zato je dodatni motiv uredništva časopisa da predmet nacionalne sigurnosti $i$ izvještajnog djelovanja približi javnosti i podvrgne znanstvenoj evaluaciji. A to je prvi korak kako bi područje nacionalne sigurnosti $i$ izvještajnog rada postala akademska disciplina $i$ u tranzicijskim zemljama. Zato radovi objavljeni u ovom časopisu moraju zadovoljiti visokim znanstvenim standardima, koji vrijede kao i za ostale znanstvene časopise.

Međutim, namjere uredništva, ugled gosta rednika a ni sadržaj prvoga broja nisu mogli spasiti časopis NSF od javne stigmatizacije, niti uredništvo od sotonizacije. Komentatoru 
Globusa Branimiru Donata već sama činjenica da je promocija časopisa održana u atriju NSK bila je za osudu: „.. bio sam po malo zgranut zbog pomanjkanja dobrog ukusa i demonstriranja 'znanstvenosti' projekta bivšeg šefa jedne tajne službe, koju je nova građanska koncepcija političke prakse s razlogom defenestrirala“. Za njega je „Pothvat koji je tako neprimjereno održan u NSB-u" sporan jer su na promociji bili 'neki bivši ljudi' što je nespojivo s demokracijom: „za demokraciju spornoj, a za NSB više nego neukusnoj, promociji bili su sve neki bivši, da ne kažem ljudi, ali barem prošli dužnosnici“. A sve te „bivše ljude“ B. Donat poručuje da treba eliminirati iz javnoga života: „Sve mi se čini da su i sve naše i njihove tajne službe bile promašene investicije i gorčinu koju svakodnevno osjećamo i pri samom njihovu spominjanju jedino mogu ublažiti i sljedeće defenestracije skupih diletanata 'nevladine i nestranačke Udruge sv. Jurja'“. Kolumnist Globusa nije zadovoljan eliminiranjem ljudi okupljenih na projektu NSF-a samo iz atrija NSK-a, pa svoju kolumnu adresira "tamo gdje to treba" radi trajne defenestracije: ,jedino mogu poželjeti da i ova kolumna ima odjek tamo gdje to treba". ${ }^{7}$

Branimir Donat u svoje je vrijeme bio ugledni književni kritičar, esejist, publicist $\mathrm{i}$ prevoditelj. Zato njegov prikaz promocije NSF-a, osim političkog dodvoravanja reformiranim komunistima koji su došli na vlast početkom 2000. godine, pokazatelj je potpune neupućenosti u rad i ulogu hrvatskih izvještajnih službi tijekom 1990-ih godina, te apriornog odbijanja i razumijevanja njihove uloge u suvremenome svijetu.

Profesor Stevan Dedijer, predavao je na Lund sveučilištu Business Intelligence od 1972. i jedan je od prvih promotora Open-source intelligencea, ${ }^{8}$ dao je sljedeću ocjenu prikaza promocije prvog broja časopisa NSF-a u medijima:

Vjesnik dobar, Večernji list dovoljan, Jutarnji list nula $i$ dovoljan, Globus nula, Feral Tribune nula, Nacional do 16 lipnja mudro šuti... Na skali od najgore nula do najbolje odličan - to su moje ocjene s kakvom su objektivnosti spomenuti listovi predstavili javnosti promociju međunarodnog časopisa Miroslava Tuđmana o

7 Branimir Donat: "Obavještajni bilten Miroslava Tuđmana je za kioske, a ne za promociju u NSB-u!", Globus, 16. lipnja 2000. Godine.

8 Open-source intelligence (OSINT) - Izvjesnice iz otvorenih izvora su podaci prikupljeni iz javno dostupnih izvora koji se koriste u izvještajnim procjenama. U izvještajnoj zajednici izraz "otvoreni" odnosi se na otvorene, javno dostupne izvore (za razliku od prikrivenih ili tajnih izvora). (https://en.wikipedia.org/wiki/Open-source_intelligence) 
obavještajnim službama National Security and the Future....

Komentar Feral Tribunea o promociji sveo se na osobni napad na profesora Tuđmana i staljinističko-balkanski pristup obavještajnim službama da se isključivo bave špijunažom. $U$ najrazvijenijim zemljama danas se špijunaža gotovo potpuno zamijenila informacijom iz otvorenih izvora i smatra se kao drugostepena, nezakonita tehnika. Globus također vidi obavještajne službe samo kao „špijunažu“.

Nijedan od prisutnih dopisnika nije zabilježio nijedan od mnogobrojnih signala u časopisu o dubokim promjenama tih službi, u razvijenim zemljama s kojima Hrvatsku sada mora da surađuje...9

Prvi broj časopisa NSF objavljen je nepunih šest mjeseci nakon pobjede "šestorke" 10 na čelu S SDP-om i uspostave nove parlamentarne većine i Vlade premijera Ivice Račana. Časopis koji je imao ambiciju baviti se strategijama nacionalne sigurnosti i europske stabilnosti, na samom svom početku postao je sam žrtva medijskih politika i političkih promjena. Provladini mediji i novinari dočekali su NSF sa zahtjevom "trajne defenestracije“ uredništva, što je bilo i stajalište nove službene politike 2000. u kojoj su glavnu riječ imali „reformirani“ komunisti. Time je doseg ambicija i djelovanja časopisa NSF unaprijed bio osuđen i sveden na minimum u medijskome i političkom prostoru što ga je oblikovao novi režim.

U pozadini političkih promjena i medijskih politika u $\mathrm{RH} 2000$ te bila je strategija onih međunarodnih čimbenika koji su imali za cilj zapadnobalkanske integracije, jer se nisu mogli pomiriti $\mathrm{s}$ raspadom Jugoslavije a niti pristati na nove zahtjeve za priznanjem nacionalnih država na Balkanu. Zato je predizbornoj koaliciji šest stranaka politički pristanak na „zapadnobalkanske integracije“ osigurao materijalnu, medijsku i političku potporu onih međunarodnih čimbenika koji su Hrvatsku vidjeli u obnovi zapadnog Balkana. Međutim, zapadnobalkanske integracije u suprotnosti su s Ustavom $\mathrm{RH}$ koji zabranjuje udruživanje $\mathrm{RH}$ s bivšim republikama SFRJ,

9 Stevan Dedijer, Vjesnik, pisma čitatelja, 24.6.2000.

10 Koaliciju šest stranaka činili su: SDP (43) i HSLS (25), te HSS (17), HNS (2), IDS (4), LS (2). U zagradi je broj izabranih zastupnika u Hrvatskome saboru. Prema koalicijskom sporazumu bilo je unaprijed dogovoreno da će se imenovanja na funkcije u budućoj koalicijskoj vlasti dijeliti po ključu 50 posto za SDP, 25 posto za HSLS i 25 posto za preostale četiri stranke. 
odnosno zabranjuje udruživanje koje bi moglo dovesti do „neke „balkanske državne sveze u bilo kojem obliku“. ${ }^{11}$

Namjere jednih i pristanak drugih na zapadni Balkan imali su za posljedicu snažne turbulencije na hrvatskoj političkoj sceni jer je mogući ishod vladajuće politike bio u suprotnosti $s$ ustavnim odredbama države koja tada još nije obilježila ni desetu obljetnicu svoje neovisnosti. Te su politike turbulencije utjecale na difamaciju časopisa NSF od provladinih medija već na početku njegova izlaženja.

Ocjena uredničke politike, tj. sadržaja, značenja i vrijednosti objavljenih tekstova, te uloge časopisa NSF u stvaranju novoga znanstvenoga područja ne može biti cjelovita ako se ne prikažu uvjeti i okolnosti u kojima se časopis pojavio 2000. godine. NSF je trebao proučavati europske i nacionalne strategije a sam je postao žrtvom strateških odrednica međunarodne političke. Zato je nužno naznačiti: a) strateške ciljeve međunarodne politike zapadnobalkanskih integracija i posljedice na razvoj $\mathrm{RH} 2000$-ih godina; b) posljedice politike „ili se pokloni ili se ukloni“ na demontiranje sustava nacionalne sigurnosti formiranog 1990-ih godina.

\section{Konfuzne strategije „novog imperijalizma“}

\subsection{Motivi i ciljevi strategije zapadnobalkanskih integracija}

Hrvatska je u završnim vojno-redarstvenim operacijama Bljesak i Oluja 1995. sama i samostalno oslobodila okupirana područja $\mathrm{RH}$. U nastavku tih vojnih operacija u $\mathrm{BiH}, \quad \mathrm{HV}$ i HVO zajedno s Armijom BiH došli su dvadesetak kilometara do Banja Luke. Vojska Republike Srpske bila je pred porazom, a velikosrpska politike poražena. Vojni uspjesi hrvatske politike prisilili su i srpsko i bošnjačko vodstvo da dođu u Dayton i potpišu Daytonski sporazum. Vojna i politička situacija potpuno se promijenila zbog uspješnih operacija Hrvatske vojske - a ne zbog neučinkovitosti mirovnih snaga UNPROFOR-a i jalovih diplomatskih napora međunarodne zajednice.

Uloga Hrvatske politike i vojske bila je činjenica koja se uvažavala i nije osporavala do Daytona i u Daytonu. Međutim, velike sile nisu mogle prihvatiti da nakon Daytona imaju sporednu ulogu u uspostavi budućih odnosa između država nastalih raspadom Jugoslavije. Zato nisu htjeli Hrvatsku priznati za partnera u postdaytonskom razdoblju, 
paradoksalno, zbog njezinih zasluge za završetak rata u RH i BiH.

Da bi se pobjedniku oduzelo pravo na pobjedu, potrebno je redefinirati medijsku sliku stvarnosti i politička pravila ponašanja. Tome služe strategije i zato je 1995. osnovana međunarodna komisija koja je imala "mandat da izradi izvještaj o situaciji na Balkanu i formulira dugoročne mjere"12. Taj je mandat povjeren Zakladi Carnegie i Aspen Institutu zajedno s nekoliko drugih europskih i američkih zaklada ${ }^{13}-$ što je imalo "za posljedicu jedinstvenu suradnju: američke i europske zaklade našle su se na zajedničkom poslu. Bio je to jedinstven transatlantski uspjeh". ${ }^{14}$

Taj "jedinstven transatlantski uspjeh" napisan je u formi Izvještaja Međunarodne komisije za Balkan, a objavljen pod naslovom Nedovršeni mir. Izvještaj polazi od uvjerenja da je "prevladavajući mentalitet na Balkanu trajna prijetnja miru, užasavajući primjer netolerancije i sramota za Europu“. ${ }^{15}$ Polazeći od takve postavke Međunarodna komisija za Balkan smatra da se na području bivše Jugoslavije, kojeg oni stalno nazivaju Balkan - te na kojem prema njima žive "balkanski narodi" - vodio "treći balkanski rat". Da bi se ta "sramota za Europu" stavila pod kontrolu, Tindemansova je komisija svoj izvještaj formulirala u 57 preporuka koje su "namijenjene zapadnim vladama i nevladinim organizacijama, kao i vladama i nevladinim organizacijama u regiji"16. Prvih trideset preporuka odnose se na pojedine zemlje "na Balkanu", a preporuke od 31 do 57 artikuliraju mjere i postupke kojima je cilj "stvaranje Južnobalkanske konfederacije".

Međunarodna komisija za Balkan predlaže dvije inačice ostvarenja svoje strategije. Prva je "Međunarodna konferencija o sigurnosti na Balkanu", a druga "još ambicioznija inicijativa" vodila bi "Konferenciji o južnom Balkanu, pod pokroviteljstvom Sjedinjenih Država i Europske

12 Nedovršeni mir: Izvještaj Međunarodne komisije za Balkan. / predsjednik Leo Tindemans. Zagreb: Hrvatski helsinški odbor za ljudska prava; Sarajevo: Pravni centar FOD BiH, 1997., str. IX.

13 Članovi Međunarodne komisije za Balkan bili su: Simone Veil, John Roper, Theo Sommer, Lloyd Cutler, Bronislaw Geremek, David Anderson te predsjednik Leo Tindemans. Komisiju je osnovala Carnegie Endowment for International Peace, a 11 europskih i američkih fondacija financirale su rad Komisije. "The Open Society Fund (New York), grad Berlin i tvornica Siemens A.G., pružili su velikodušnu pomoć Komisiji u osoblju i opremi" (Nedovršeni mir:.., str. XIV).

14 Nedovršeni mir, str. IX-X.

15 Nedovršeni mir, str. $X$.

16 Nedovršeni mir, str. 12. 
unije, koja bi imala za cilj stvaranje Južnobalkanske konfederacije"17. Budući da je Tindemansova komisija bila svjesna činjenice da "balkanske zemlje" ne žele uči u nove "balkanske" asocijacije, preporuke sadržavaju niz mjera koje vode tome cilju: stvaranje mreže regionalnih komisija koje bi radile na "specifičnim problemima": zajedničko područja slobodne trgovine, demilitarizacija, međudržavna suradnja u sudskom progonu zločina, vjersko pomirenje i suradnja, civilno društvo, ekonomski razvoj i razvitak infrastrukture itd.

"Budu li se pojedine balkanske države opirale sudjelovanju u ovim komisijama ili čak njihovu formiranju ... vjerojatno će biti nužno da Zapad pribjegne pritisku, tj. da iskoristi žarko priželjkivano 'prihvaćanje' balkanskih država od strane Europe"18. Zato je preporuka europskim vladama da mogu s "balkanskim zemljama" sklapati i bilateralne ugovore ali "svaka strana mora biti natjerana da shvati"19 i prihvati "predložena" rješenja.

Za Međunarodnu komisiju za Balkan „Srbija ostaje najvažnija država jugoistočne Europe“, a Milošević „čovjek bez kojeg se ne može“. 20 Hrvatska je pak država koja mora prihvatiti predložena rješenja u okvirz zapadno-balkanskih integracija.

Tindemansova komisija smatra "da je za početak politički najrealnije i ekonomski najkorisnije stvaranje područja slobodne trgovine jer bi to državama članicama osiguralo najviši stupanj ekonomskog i političkog suvereniteta". Ova konstatacija implicite sadrži pretpostavku da bi "balkanske" države samo "za početak" osigurale "ekonomski i politički suverenitet", a da bi ta integracija vodila reduciranju suvereniteta država članica uključenih u balkanske asocijacije.

Hrvatska službena politika tijekom 1996. i 1997. jasno je dala do znanja da ne pristaje na regionalne jugo-balkanske asocijacije i integracije. Jer nije željela da se po treći put ponovi, pa makar i pod nekim novim imenom, eksperiment zvan Jugoslavija, koji se dva puta pokazao neuspješnim i poraznim za Hrvate i Hrvatsku. Unatoč tome Međunarodna komisija za Balkan smatra da su regionalne integracije na području bivše Jugoslavije nužnost i da je „stvaranje Južnobalkanske konfederacije" najbolje rješenje.

17 Nedovršeni mir, str. 140 .

18 Nedovršeni mir, str. XI.

19 Nedovršeni mir, str. XXVII.

20 Nedovršeni mir, str. 107,109. 
Međunarodna komisija predlaže i formiranje posebnoga suda koji bi imao zadaću onemogućiti priznavanje novih država na Balkanu, a svojim djelovanjem postojeće prisiliti na balkanske integracije. Na taj način institut nepovredivosti postojećih granica, bio bi važniji od prava naroda na samoodređenje. Posredno bi se pak priznalo da je raspad SFRJ bila pogreška, pa iz preventivnih razloga treba „utemelji međunarodni sud ... koji bi imao dužnost razmišljati o granicama samoodređenja i koji bi, zapravo, pomogao pri razrješavanju napetosti između prava na samoodređenje, o kojemu govori Povelja Ujedinjenih nacija, i čvrstog zauzimanja međunarodne zajednice za nepovredivost granica“. ${ }^{21}$

Stajališta Međunarodne komisije za Balkan imala su utjecaja i na EU koja je godinama odbijala priznati da je zapadni Balkan dio Europe i europski problem. Za Bruxellesu nije bilo prihvatljivo „zapadni Balkan“ poistovjetiti s ,jugoistočnom Europom" jer:

Upotreba termina "Jugoistočna Europa" umjesto termina "Zapadni Balkan" implicirala bi priznavanje činjenice da ova regija već čini dio Europe, da su njeni problemi Europski problemi i da bilo koje održivo rješenje mora biti Europsko rješenje koje će uključivati $i$ ovisnost o Uniji $i$ njezino širenje. ${ }^{22}$

Time je Balkan, odnosno zapadni Balkan, postao i ostao prostor za „izvoz demokracije“ s ciljem promocije globalističkih vrijednosti "liberalne“ demokracije kojoj su nacije, nacionalne države i nacionalni identiteti, te demokršćanske vrijednosti, samo zapreka za uspostavu planetarnoga potrošačkog društva i globalnoga poduzetništva.

\subsection{Svi se trebaju odreći sna o suverenosti}

Velika Britanija usvojila je novu imperijalnu politiku, koju je razradio Robert Cooper 2001., vanjskopolitički savjetnik Tonyja Blaira te bivši direktor političko-vojne uprave pri Europskom vijeću. ${ }^{23}$ Novi imperijalizam nema više za cilj osvajanje teritorija jer se imperijalizmu globalnoga

\footnotetext{
21 Nedovršeni mir, str. XX.

22 Zemlje na Balkanu i nove europske odgovornosti. Strategijski nacrt prezentiran na sastanku "Kluba trojke i zemalja na Balkanu". Brusseles, 29-30 lipanj 2000. Dr. Win van Meurs, C.A.P, 19.06.01.

23 To je jedna od najviših vanjskopolitičkih dužnosti u okvirima EU-a. Carole Hodge, Velika Britanija i Balkan. Zagreb : Detecta, 2007.,str. 370.
} 
gospodarstva „dragovoljno izlažemo“.24 Drugi oblik suvremenog imperijalizma jest „obrambeni mehanizam“ od „propadajućih država“ pa je potrebno uspostaviti zaštitne mehanizme, "gotovo ograde“ oko nestabilnih država.

Globalno integriranje prati politička dezintegracija ili rastakanje, što je na Balkanu i na nekim drugim mjestima dovelo do stvaranja novih, slabijih država, koje, po Cooperu, znače prijetnju kaosom i kojima valja u ime interesa ostalog dijela svijeta pružiti pomoć. Na toj točki valjalo bi otvarati prostor 'obrambenom', 'dragovoljnom' imperijalizmu, ili pak 'kooperativnom imperiju'. Susjedi se počnu okupljati, jači uz slabije, i stvaraju svjetski poredak u kojemu više neće tako lako postajati plijenom za međunarodni kriminal i prijetnje oružjem masovnog uništenja. To nije sustav u kojemu se nešto nameće, nego je riječ o, kako ga Cooper naziva, sustavu samonametanja, u kojemu, ako ih se na to potakne, ostale države mogu zaželjeti da žive dragovoljno umanjujući svoju takozvanu suverenost. ${ }^{25}$

To nije sustav kojim se nekom nešto nameće, nego je to "sustav samonametanja“ i "dragovoljnog“ uzmaka od „takozvanog“ suvereniteta. Od globalnih aktera ne očekuje se odricanje od „svoje takozvane suverenosti“. Protudržavna paradigma mehanizam je nametanja dvostrukih kriterija koji vrijede za tranzicijske države u međunarodnim odnosima, a da bi se dala legitimacija novim imperijalnim politikama. Jer Velika se Britanija i EZ trebaju poslužiti i „okrutnijim metodama“ u provedbi nove imperijalne politike: „... kada imamo posla sa staromodnijim vrstama država izvan prostora postmodernog europskog kontinenta, moramo ponovno posegnuti za nekim okrutnijim metodama iz prethodnog razdoblja - sili, prevenirajućem napadu, varci, odnosno, svemu nužnom za rješenje problema i postizanje cilja u odnosu na nekog tko još živi u devetnaestom stoljeću, kada je vrijedilo načelo 'svaka država za sebe' ..."26

U praksi međunarodnih odnosa „sustav samonametanja“ i „dragovoljnog“ uzmaka od „takozvanog“ suvereniteta svodi se na politiku ,ili se pokloni, ili se ukloni“. ${ }^{27}$ Sprega međunarodnih

24 Naredne su formulacije i teze preuzete iz: M. Tuđman „Međunarodni poredak i mali narodi u djelu povjesničara i državnika Franje Tuđmana“, Kolo, 3-4/2010, str. 99-123

25 Carole Hodge, str. 371.

26 Carole Hodge, str. 371.

27 „Ili se pokloni, ili se ukloni“ podnaslov je u knjizi Z. Tomca (Predsjednik protiv predsjednika. Zagreb: Detecta, 2005.), koji vrlo precizno 
čimbenika koji stvaraju „crne liste“ onih koje treba „ukloniti“ i medija koji sustavno diskreditiraju one koji se nisu "poklonili“ više je nego očita. „Svaki političar na Balkanu, nažalost i u Hrvatskoj ... koji nije spreman bespogovorno, ponizno i pokorno provoditi naloge 'međunarodne zajednice', dolazi na tajnu crnu listu te ga se na različite načine sustavno sotonizira, banalizira, diskreditira pa čak i kriminalizira. $\mathrm{Ne}$ samo njegovu politiku nego i njega kao osobu“. ${ }^{28}$

Strateški ciljevi Međunarodne komisije za Balkan i nove imperijalne "politike samonametanja“ postali su Biblija za niz "nevladinih organizacija" te alternativnih medija koji su financirani iz istih ili srodnih izvora kao i Tindemansova komisija, a kojima je jedan od najutjecajnijih pokrovitelja i jedan od glavnih donatora bio je George Soros. ${ }^{29}$

George Soros bio je protiv raspada Jugoslavije i priznanja novih nacionalnih država. Zato ne iznenađuje što je Soros 1996. godine svojim sljedbenicima u Zagrebu rekao da potpisuje bianco ček za prikupljanje fabriciranih dokaza za haške optužnice kako bi se donijela presuda da je hrvatska država stvorena na zločinu. Svi su ti potezi bili u funkciji

određuje odnos međunarodne zajednice prema hrvatskim političarima koji jesu, odnosno nisu, provodili naloge "međunarodne zajednice".

28 Z. Tomac, 2005., str. 27. I dalje: „To je glavni razlog zbog kojega su političari 'međunarodne zajednice', a posebno britanski, koji su se u tome isticali, mrzili Franju Tuđmana, a za života ga rušili svim sredstvima, odnosno, zbog kojih im je i danas, šest godina poslije smrti, najveći protivnik, zbog kojeg je njegovo životno djelo - Hrvatsku kao nacionalnu državu hrvatskog naroda, žele rastočiti, promijeniti pa i srušiti?".

29 Izvješće Međunarodna komisija za Balkan legalizirao je djelatnost tzv. „nevladinih“ i vladinih organizacije, Soroseve zaklade Otvoreno društvo i njihov program rušenja demokratskih Vlada pogotovo u državama nastalim raspadom komunističkog poretka, vladama koje nisu bile spremne odreći se svojega suvereniteta i pristati na diktate globalističke filozofije.

George Soros utemeljio je zakladu Otvoreno društvo, kako bi financirao sve one političke, obrazovne, znanstvene i kulturne programe koji su slabili ili rušili nacionalne države i jake nacionalne stranke. Soros je nacionalne države smatrao smetnjom globalnom tržištu i stvaranju globalnoga društva koje bi trebalo imati jednu vladu, valutu, tržište, itd. 
rušenja HDZ-ove vlasti. ${ }^{30}$ Što je i posvjedočeno u Haagu na suđenju Anti Gotovini. 31

Uspostavljena „odozdo“, na vlastitim odlukama i prosudbama, hrvatska država našla se na optuženičkoj klupi u Haagu. Optužnice su podignute protiv mrtvih i živih visokih vojnih i političkih dužnosnika. No, smisao je presuda trebao biti u discipliniranju hrvatske politike na „dragovoljni“ uzmak od "takozvanog" suvereniteta i samostalnog odlučivanja o svojoj budućnosti.

Zato je niz vladinih i nevladinih organizacija imao osigurana sredstva za programe u Hrvatskoj. Osim Soroseva Otvorenog društva ilustrativan je primjer i USAID-ova djelovanja u Hrvatskoj. USAID-ova je nazočnost na početku 1993. bila vrlo skromna. Prvi strateški petogodišnji plan donijeli su 1995. Predizborna koalicija šest oporbenih stranaka potpisana je u Washingtonu, prije parlamentarnih izbora 2000. Nakon dolaska na vlast šestorke 2000. godine, USAID-ov strateški plan za Hrvatsku 2001-2005. počinje rečenicom ".. Hrvatski put prema modernoj demokratskoj naciji i punoj participaciji u globalnoj ekonomiji započinje najranije početkom 2000. ..."32. Sve akcije i operacije koje je planirao USAID bile su anticipirane i u Tindemansovu izvješću. ${ }^{33}$

30 Zapisnik sa sastanka G. Sorosa sa djelatnicima institucija koje je financirao u RH. „Lokacija. Hotel Esplanade, soba 108, Zagreb. Datum: petak 9. veljače 1996. Prisutni: George Soros, Ištvan Rev (direktor Sorosova arhiva u Budimpešti), Karmen Bašić (izvršna direktorica Instituta Otvoreno društvo Hrvatska, član HHO), Ivan Zvonimir Čičak (predsjednik HHO), Drago Pilsel (potpredsjednik HHO), Dafinka Večerina (glavna tajnica HHO) i Petar Mrkalj (direktor ureda HHO). Trajanje: od 09.00 do 10.30 sati“.

31 Tadašnji predsjednik Hrvatskog helsinškog odbora Žarko Puhovski priznao je kako je 1990-ih HHO dobivao pola milijuna dolara godišnje za jednostrano prikazivanje zločina, zločina počinjenih samo na hrvatskoj strani. Zbog neobjektivnog $\mathrm{i}$ neistinitog prikazivanja prilika tijekom $\mathrm{i}$ nakon Oluje, Haški sud je odbacio dokumentaciju HHO-a kao nevjerodostojnu.

32 Unated States Agency for International Development: Croatia: Strategic Plan 2001 - 2005. January 2001., p. 6.

33 Soros i USAID smatrali su da su ostvarili svoje glavne ciljeve u RH te su u razdoblju 2006./2007. prestali izdašno financirati medija i NGO. To je imalo za posljedicu bankrot medija koji su održavani na životu samo zahvaljujući svojim sponzorima koji su ih financirali, a ne objektivnome informiranju i utjecaju što su ga imali u javnosti. Bankrotirali su u kratkome vremenu: Feral, Nacional, Radio 101, itd. Djelovanje novinara u tim i takvim medijima, slikovito je opisala Tanja Torbarina: „svi smo novinari ali nismo ista profesija“. 


\section{Posljedice politike „Ili se pokloni ili se ukloni“}

Pobjeda u "Oluji" Hrvatsku je učinila ne samo pobjedničkom nego i respektabilnom regionalnom silom, s izgrađenim i jakim sustavom nacionalne sigurnosti. Međutim, nevladine organizacije i „alternativni“ mediji odradili su svoj posao koncem 1990-ih na promjeni vlasti kako bi se Hrvatskoj nametnuli strateški ciljevi koji nisu bili njezin izbor. ${ }^{34} \mathrm{~S}$ novim predsjednikom države Stjepanom Mesićem i predsjednikom Vlade Ivicom Račanom, nova je državna politika ispunila očekivanja stratega "samonametanja" zapadnog Balkana.

U Zagrebu se 24. studenog 2000. održao summit o zapadnom Balkanu. Hrvatska je tako prvi put u svojoj povijesti postala dio Balkana. George Soros, jedan od pokrovitelja zapadnobalkanskih integracija vrlo jasno je objavio što se očekuje: prvo, u roku od godine dana da se uvede carinska unija s prvenstvom pristupa tržištu EU-a; drugo, do dvije godine uvede regionalni porez na dodanu vrijednost. ${ }^{35}$

Na putu koji je Hrvatsku trebao odvesti na zapadni Balkan državna je politika bila spremna žrtvovati pobjednički mentalitet i tijekom 1990-ih uspostavljeni sustav nacionalne sigurnosti. Novi Zastupnički dom Hrvatskog državnog Sabora 14.4.2000. donosi 'Deklaraciju o suradnji s međunarodnim kaznenim sudom u Haagu'. ${ }^{36}$ Time je Hrvatska pristala na politiku haškoga tužiteljstva koja se „temelji na stavu da su svi ratni lideri svih strana krivi za ratne zločine, a da zatim razmatra koji su to određeni zločini i kako da dokaže njihovu krivicu“. ${ }^{37}$ Od 2001. u Zagreb počinju dolaziti iz Haaga tajne i zapečaćene optužnice i zahtjevi za uhićenjima. Saborska Deklaracija legalizirala je sudsku i medijsku kriminalizaciju Domovinskoga rata i progon hrvatskih branitelja, koji će trajati sve do oslobađajućih presuda generalima A. Gotovini i M. Markaču.

34 Prema pouzdanim izvorima čak su 120 milijuna dolara potpore dobile razne udruge, stranke i mediji u protu-hdzeovskoj kampanji 1999. godini.

35 Vjesnik 6.12.2000.: George Soros, biznismen svjetskoga glasa za slovački list SME piše o povijesnoj prilici za povezivanje regije.

36 U točci 3., između ostaloga se navodi: - Republika Hrvatska ne dovodi u pitanje pravo Suda da pokreće postupke utvrđivanja odgovornosti za zločine počinjene za vrijeme i neposredno nakon završetka Domovinskog rata!

37 William Montgomery „Kad ovacije utihnu“. (Struggling with democratic transition; After the cheering stops, 2010) str.114. 
U otvorenom pismu hrvatskoj javnosti 28. rujna 2000. dvanaestorica generala hrvatske vojske tražili su da se zaštiti dignitet Domovinskog rata:

... pozivamo najodgovornije osobe i institucije države, kao i mjerodavne čimbenike civilnog društva, a napose medije, da se odupru negativističkom i povijesno nekorektnom $i$ neistinitom prikazivanju Domovinskog rata, da zaštite čast i dostojanstvo hrvatskih časnika i vojnika, da ne podliježu klimi olakog optuživanja i blaćenja, jer time se štite ne samo temelji na kojima je uspostavljena hrvatska sloboda $i$ državna neovisnost, nego, a u to smo duboko uvjereni, $i$ temelji na kojima jedino može počivati budućnost demokratske i prosperitetne Hrvatske ${ }^{38}$

Predsjednik RH Stjepan Mesić odmah je umirovio djelatne generale potpisnike Otvorenoga pisma: „Sedam generala sam umirovio jer su državu htjeli rušiti pamfletom ... Od danas, oni više nisu pripadnici Hrvatske vojske“. ${ }^{39} \mathrm{Od}$ dvanaestorice potpisnika Otvorenoga pisma u Haagu su završili general pukovnici Ivan Čermak i Ante Gotovina, te general Mladen Markač 40

Haški je Tribunal postao učinkovit instrument ne samo kriminalizacije Domovinskoga rata nego i trajnoga pritiska i discipliniranja hrvatske službene politike radi "dragovoljnog“ uzmaka od „takozvanog“ suvereniteta i pristanka na zapadnobalkanske integracije. A službena se politika narednih desetak godina pokrivala mantrom da je Hrvatska bila u međunarodnoj izolaciji već nakon Oluje jer Tuđmanov „režim“ nije pristajao na međunarodne planove o regionalnim integracijama (od poznatog plana Z4, te tzv. Bildtova plana $6+1-1$, itd.) u nove/stare zapadnobalkanske asocijacije, te

38 Otvoreno pismo dvanaestorice hrvatskih ratnih zapovjednika hrvatskoj javnosti potpisali su 28.9.2000. godine: stožerni general u mirovini Janko Bobetko; admiral Davor Domazet Lošo; general pukovnik Ivan Čermak; general pukovnik u mirovini Ivan Basarac; general pukovnik Krešimir Ćosić; general pukovnik Ante Gotovina; general bojnik Damir Krstičević; general bojnik Ivan Kapular; general bojnik Mirko Norac; general bojnik Miljenko Filipović; general bojnik u mirovini Ivan Korade i general bojnik u mirovini Nojko Marinović. (Izvor: http://hr.wikisource.org/w/index.php?title=Otvoreno_pismo_dvanaestori ce_hrvatskih_ratnih_zapovjednika_hrvatskoj_javnosti\&printable=yes).

39 Pismo u medijima dobiva status „pisma opasnih namjera“, a „Mesić je još jednom sačuvao Hrvatsku od južnoameričkog scenarija“ jer je spriječio „vojni udar". Spasivši Hrvatsku od ,južnoameričkog scenarija“ i „vojnog udara", Mesić je otvorio prostor politici institucionalne kriminalizacije Domovinskog rata i hrvatskih branitelja.

40 General Mladen Markač nije bio potpisnik otvorenog pisma kojeg su potpisali generali HV, a Markač je bio tijekom domovinskoga rata zapovjednik specijalnih postrojbi hrvatske policije. 
zato što nije izručio svoje generale Haagu. Mantra o izolaciji postala je predizborni program oporbe 1999. godine: Koalicija HSLS-a i SDP-a ima tri cilja: izvući zemlju iz gospodarske krize i međunarodne izolacije te da Hrvatska postane demokratskom državom. ${ }^{41}$ Teza o izolaciji Hrvatske bila je poruka i međunarodnim sponzorima: želimo vlast i promjenu vlasti te zato pristajemo na regionalne integracije.

Kako bi izašla iz izolacije i Hrvatsku „uključila u svjetska kretanja“42 trebalo je promijeniti ne samo politiku nego sustavno razgraditi sustav nacionalne sigurnosti koji je Hrvatsku doveo u izolaciju. Reformirani su komunisti uradili ono što najbolje znaju. Iz policije je izbačeno 5.000 policajaca, iz vojske su izbačeni pobjednički generali, što je bio uvod u plansko kriminaliziranje i branitelja i časnika hrvatske vojske da bi se pobjednička vojska mogla rasformirati. Iz diplomacije je 2000., samo u jednom danu, povućeno i degradirano 35 veleposlanika. Iz vojnih i civilnih izvještajnih službi izbačeno je preko 300 ključnih ljudi, tako da se izvan sustava našlo više stručnih ljudi nego što je ostalo u sustavu. Rasformirana je i Obavještajna akademija jer "trećesiječanjskoj politici" nije trebalo školovanje kadrova za izvještajne službe. Bio je uništen model izvještajne zajednice stvaran 1990-ih, u tranzicijskim zemljama jedan od najsuvremenijih kako po koncepciji tako i organizaciji.

U medijima počinje 2000-ih difamacija i stigmatizacija i čelnika izvještajnih službi koja ne jenjava sve do pravomoćne oslobađajuće presude u Haagu generalima Gotovini i Markaču. ${ }^{43}$ Da se radi o istim medijskim i haškim optužnicama može se prosuditi već iz naslova medijskih članaka:

- R.D.: „Špijuni iz mraka“ (Feral Tribune, 10.06.2000).

- Zlatko Gareljić, zamjenik ministra obrane: „Vidjet ćemo SIS-ovce pred sudom" (Feral Tribune, 17.06.2000).

- Ivica Đikić: „Tuđmanovi transkripti pod embargom" (AIM, Zagreb,16.1.2001).

41 Budiša i Račan na predizbornom skupu u Makarskoj, HINA, Baza EVA, 20.12.1999

42 Stjepan Mesić, HINA, Baza EVA, 27.12.1999.

43 Dana 16. studenoga 2012. generali Markač i Gotovina oslobođeni su svih optužbi i pušteni na slobodu drugostupanjskom (pravomoćnom) presudom kojom je prvostupanjska osuđujuća presuda okarakterizirana kao nerazumna. Generala Ivana Čermaka Haaški sud je u prvostupanjskom procesu 15. travnja 2011. oslobodio po svim točkama optužnice i odmah ga pustio na slobodu. 
- Mladen Pleše: „Pokrenuta istraga protiv Mire Tuđmana i još 30 Hrvata" (Nacional, 31. 07. 2001.).

- Mladen Pleše: „Haaški sud naredio Miroslavu Tuđmanu da preda ukradene transkripte koji se tiču $\mathrm{BiH}^{\prime \prime}$ (Nacional, 28. 08. 2001).

- Marijan Balder: „I Miroslav Tuđman mora platiti svoj račun" (5.9.2001.). ${ }^{44}$

- Ivica Đikić: „Oprost Tuđmanovim špiclovima“ (AIM, Zagreb, 16.11.2001.).

- Jasna Babić: „Haaška subpoena za Miroslava Tuđmana“ (Nacional, 12. 02. 2002.).

Osnovna je poruka medijske hajke na čelnike izvještajnih službi da su ukrali, uništili, sakrili dokumente (tzv. predsjedničke transkripte) koji inkriminiraju optužene hrvatske generale, pa je zato haškome Tužiteljstvu teško doći do dokaza koje nemaju, a bez kojih Tribunal ne može osuditi optužene generale. Logika da su optuženi generali krivi, ali dokaza za to nema jer ih je netko „ukrao“ ili sakrio, nastavila se u preinačenoj inačici i 2010., kada se tvrdilo da postoje nepostojeći „topnički dnevnici“ koji su trebali dokazati „prekomjerno granatiranje“ Knina.

- B. Jelinić: „Počeo lov na Tuđmanove špijune“, (Nacional br. 766, 20 srpnja 2010.)

Bombastični naslov članka, što ga potpisuje B. Jelinić, najavljuje „u okviru dosad najveće, i zapravo prve ozbiljne istrage o mračnim tajnama obavještajne zajednice iz vremena druge polovine 90-ih“. Nakon deset godina „prva ozbiljna istraga“ ponovo treba dokazati „špijunske podvale i spletke HDZ-ova vojno-obavještajnog podzemlja“ i ,samog državnog vrha“ u „opstrukciji rada Haaškoga suda“. Prema tome istraga je „veliki policijski udar na bivše čelnike obavještajne zajednice“, jer „sada su nadležne institucije i tim osobama na tragu“. Donijeta je „odluka da se sve osobe iz vrha obavještajne zajednice posebno ispitaju i po potrebi procesuiraju“. Štoviše Jelinić zna da će se dio ispitanih „sasvim sigurno suočiti s kaznenim prijavama“, pogotovo jer

44 Marijan Balder: tiskovna konferencija Dobroslava Parage, čelnika HSP1861 u Zagrebu (5.9.2001.): „u svezi pokretanja istrage protiv gosp. Miroslava Tuđmana od strane Haaškog suda." Praga je predstavljen kao „član nekih vrlo uglednih međunarodnih organizacija poput Amnesty International, Helsinki Watch iz SAD, Međunarodne helsinške federacije iz Austrije, kao i međunarodnog društva za ljudska prava iz Njemačke“ (http://www.hsp1861.hr/vijesti1/010905maba.htm) 
je ,jedan dio obavještajnog miljea nastavio opstruirati suradnju s Haaškim sudom i nakon 2000. godine“.

- Ivica Đikić: "Miroslav Tuđman i Markica Rebić pod istragom" (Novi list 12.07. 2010).

- Ivica Đikić: „Obavještajci istražuju Tuđmana i Rebića“", (Glas Slavonije 12. 07. 2010.)

- Gordan Malić: "Tajne službe RH vodile su obavještajni rat protiv Haaga", (Jutarnji list, 12.07.2010.).

Mediji najavljuju skoru presudu hrvatskim generalima $u$ Haagu, a nakon toga i nastavak sudskoga progona čelnika izvještajne zajednice. "Neslužbeno doznajemo da presuda Gotovini i ostalim optuženim generalima možda biti donesena već u listopadu ove godine, nakon čega topnički dnevnici postaju irelevantni za dinamiku pregovora s EU. No, do tog vremena hrvatska vlada mora učiniti sve da pokaže kako tu istragu provodi temeljito. Istraga će se nastaviti i nakon donošenja presude u Haagu, tvrdi sugovornik Jutarnjeg lista i član Savjeta za suradnju s Haškim sudom, sve dok ne budu kažnjeni odgovorni za nezakonito raspolaganje vojnim i službenim tajnama bez obzira na kojoj se razini zapovijedanja nalazili.“45

U organizaciji tzv. nevladinih organizacija 12. ožujka 2012. održan je u Zagrebu skup o suđenjima za ratne zločine. ${ }^{46} \mathrm{Na}$ tom su skupu sudjelovali i tadašnji predsjednik RH Ivo Josipović sa suradnicima (bili su nazočni glavni analitičar predsjednika Republike Dejan Jović te savjetnik za nacionalnu sigurnost Saša Perković), predsjednik Vrhovnog suda RH Branko Hrvatin, predstavnici Ministarstva pravosuđa, županijskih sudova, tadašnji državni odvjetnik Mladen Bajić sa svojim zamjenicima, itd.

Osnovna poruka skupa bila je „Bez utvrđivanja kaznene odgovornosti Vladimira Šeksa, Davora Domazeta Loše, Miroslava Tuđmana, Jure Radića, Ivana Vekića, Ivana Jarnjaka, Mate Laušića i drugih osoba na najvišim vojnim i političkim funkcijama zbog propuštanja sprječavanja i kažnjavanja svojih podređenih u počinjenju zločina, ne može doći do potpune i cjelovite katarze društva koje bi trebalo

45 Jutarnji list, 12.07.2010. (http://www.jutarnji.hr/miroslav-tudman-imarkica-rebic-pod-istragom-zbog-topnickih-dnevnika-/846287/)

46 Skup su organizirali: Documenta - Centar za suočavanje s prošlošću, Građanski odbor za ljudska prava te Centar za mir, nenasilje i ljudska prava iz Osijeka. Izvješće je u ime Pusićeva GOLJP-a podnio Marko Sjekavica. 
preuzeti dio odgovornosti za zločine počinjene u njegovo ime." 47

Nazočnost najviših političkih i sudskih i pravosudnih dužnosnika ovakvom skupu i ovakvim zahtjevima osigurava legitimitet, ali je i jasna politička poruka najširoj javnosti osam mjeseci prije izricanja konačne presude generalima Gotovini i Markaču. Najavljen je scenarij za progone nakon izricanja haške presude, scenarij kojeg je trebalo sprovesti radi osude i ključnih pripadnika „udruženog zločinačkog poduhvata“ kako bi došlo do „potpune i cjelovite katarze društva“.

Scenaristi i akteri kriminalizacije Domovinskoga rata i lažnih optužbi hrvatskih dužnosnika čekali su samo pravomoćnu presudu generalima Gotovini i Markaču. Jutarnji list nije mogao sačekati ni izricanje presudu, već je ujutro 16. studenog 2012. izašao s naslovom "Danas je presuda Tuđmanovoj Hrvatskoj".

\section{Na crnoj listi}

U trenutku kada je promoviran prvi broj časopisa National Security and the Future, nositelji tog projekta već su bili na crnoj listi javnih i državnih neprijatelja. Projekt koji je imao ambiciju baviti se „razvojem i razumijevanjem načela i prakse izvještajne djelatnosti i nacionalne sigurnosti u suvremenoj povijesti i vanjskoj politici“ bio je osuđen na neuspjeh, jer su njegovi nositelji i suradnici postali predmetom istraga izvještajnih službi i, kako su to zdušno najavljivali provladini mediji, kandidati za Haag.

U takvim okolnostima odbijeni su svi zahtjevi za financiranjem časopisa. Nakladnik je od početka bila Udruga sv. Jurja, koja je 1999. registrirana kao znanstvena udruga. NSF je objavljivao recenzirane znanstvene i stručne radove, ali zahtjevi za financiranje i časopisa i Udruge sv. Jurja nikada nisu dobili traženu financijsku potporu. Jedan od formalnih razloga bila je i činjenica da područje bavljenja časopisa nije bilo priznato u važećoj klasifikaciji znanosti. Budući da nacionalna sigurnost i izvještajna djelatnost nisu priznati kao znanstveno područje - to je „sukladno važećim propisima i pravilima“ odbijano financiranje NSF iz sredstava predviđenih za financiranje znanstvenih časopisa i projekata.

47 Uvodnu riječ na skupu dao je šef Delegacije EU u RH Paul Vandoren s porukom „To je povod da i javno zatražim od hrvatskih vlasti da nastave surađivati s trima organizacijama na općem osnaživanju nacionalnog pravnog sustava“. 
Birokratska logika i politička difamacija osujetili su ambiciju uredništva da „područje nacionalne sigurnosti i izvještajnog rada postane akademska disciplina i u tranzicijskim zemljama“. Proći će 16 godina da se „sigurnosne i obrambene znanosti“ uvrste u područje društvenih znanosti. ${ }^{48}$ Po objavljivanje NSF posljedice su bile očite. Bez osiguranih sredstava iz javnih fondova, tiskanje časopisa bilo je moguće samo zahvaljujući nekolicini donatora. Nedostatak financijske potpore bio je i razlogom da smo broj objavljenih svezaka godišnje s četiri morao smanjiti na tri (od 2014). Svi poslovi na recenziranju, uređivanju, prevođenju, lektoriranju, prijelomu, itd. od samoga početka rađeni su bez naknade.

Časopis je pod takvim uvjetima mogao izlaziti u tiskanoj formi do 2007. godine. Nakon toga dostupan je samo on-line. No, od 2016. godine pojedini bojevi NSF-a se i tiskaju. Tiskaju se radovi sa Zagreb Security Foruma jer je Udruga sv. Jurja jedan od organizatora tog međunarodnoga skupa.

Crna lista na kojoj se našlo uredništvo i NSF imala je presudnu ulogu i na uređivačku politiku. Područje kojem je bio posvećen časopis $\boldsymbol{N S F}$ trebali smo istraživati kao neovisni analitičari i distancirani znanstvenici. Međutim, dio uredništva i suradnika iz Hrvatske postali su predmetom istraživanja izvještajnih i sigurnosnih službi, a strateški planovi i ciljevi hrvatske politike 1990-ih predmetom osude i kriminalizacije tada aktualne politike i haških optužnica. U medijskom prostoru bili smo izloženi klevetama, krivotvorinama, lažima, optužbama - uvriježenim tehnikama specijalnih operacija u informacijskom ratu. Mi koji smo do 2000. godine predavali na Obavještajnoj akademiji, Diplomatskom akademiji ili Ratnoj školi Hrvatskog vojnog učilišta (M. Međimorec, admiral Davor Domazet-Lošo, Ivo Lučić, M. Tuđman) ${ }^{49}$ postali smo persone non grata narednih desetak godina u tim ustanovama.

Politička garnitura koja je dobila izbore 2000. bila je mješavina naslijeđenih mentalnih komunista, novopečenih liberala $\mathrm{s}$ filozofijom globalizacije i jugonostalgičara koji su preko volje prihvatili hrvatsku državu. Nastupili su zajedno s sloganom osude „Tuđmanova režima“ i njegovih „deset mračnih, izgubljenih godina“. Bez iskustva i kompetencija u vođenju države primijenili su svoje stare oprobane metode: „crne liste“ za čistku ljudi „Tuđmanova režima“ iz javnosti i političkih

48 Pravilnik o znanstvenim i umjetničkim područjima, poljima i granama (Pročišćeni tekst - „Narodne novine“ broj 118/09, 82/12, 32/13 i 34/16 - neslužbeni)

49 Spominjem samo članove uredništva, ali to se odnosi i na druge suradnike NSF-a koji su radili u sustavu nacionalne sigurnosti do 2000 . godine. 
struktura. Imali su moć izbaciti tisuće ljudi iz državnih institucija, ali ne i dokaze za bilo koga optužiti za nepoštivanje zakona ili kriminal.

Za svoju politiku imali su potporu hrvatskoga žutog tiska i medija koji su prihvatili Soroševe novce i njegovu filozofiju osude nacionalnih država. Imali su potporu i u onim međunarodnim krugovima koji su smatrali da je bila pogreška pristati na raspad Jugoslavije, pa su zagovarali neke nove zapadnobalkanske integracije. Svi su oni ulagali velike napore iskoristi haški Tribunal kao batinu za obračun $\mathrm{s}$ ljudima koje su stavili na crne liste.

Međutim, velika je razlika između medijske slika stvarnosti što je nameće nesposobna vladajuća garnitura te procjene realnosti i budućih događaja od strane izvještajnih službi. Moje me višegodišnje iskustvo u suradnji sa stranim izvještajnim službama, tijekom rata i ratova na području bivše Jugoslavije, uvjerilo da nema bitnih razlika između službi u procjeni situacije, ocjeni aktera i događaja. Čak i onda kada njihovi primarni korisnice donose odluke i vode različite politike. Poznavanje činjenica je zajedničko svima, no politički interesi nisu.

Nakon smrti prvoga hrvatskoga predsjednika u uredništvu NSF prelamale su se te dvije oprečne slike hrvatske političke realnosti. Aktualna politika bavila se „revizijom povijesti“ tj. prvih deset godina hrvatske države te kriminalizacijom Domovinskoga rata. Urednici i suradnici NSF bili su sotonizirani u domaćim medijima. $U$ isto sam vrijeme sa svih strana primao izraze sućuti od šefova izvještajnih službi, koji su znali da povijesne činjenice nisu podložne nasilnim preinakama, te da su svi takvi pokušaji kratkoga vijeka.

Primio sam nekoliko desetaka izraza sućuti od direktora službi s kojima je HIS surađivao. Poruke su u većoj ili manjoj mjeri otvoreno sadržavale pohvalu i zahvalu predsjedniku Tuđmanu. Za ilustraciju potrebno je navesti nekoliko primjera.

Gospodine Ravnatelju!

$S$ velikim osjećajem i beskrajnom tugom saznao sam za smrt Vašega oca, Predsjednika Tuđmana. Kao i čitav francuski narod, tako je $i$ mene zaprepastila $i$ rastužila ta vijest. ... Odlaskom jednog od svojih najodličnijih ljudi Hrvatska gubi i svoga oca - utemeljitelja.

Karizmatični vođa, on na velika vrata ulazi u Povijest $i$ ostavlja za sobom spomen kao političar čvrstih uvjerenja, ali i kao žestoki borac kojega su uvijek ispunjavali urođeni 
osjećaj za narod $i$ sasvim posebna samozatajnost $U$ ovim teškim prilikama želim Vam svim srcem da nađete $u$ svojih bližnjih odanost, hrabrost i utjehu, kako biste nadvladali ovo bolno iskušenje.

Jacques Dewatre ${ }^{50}$

.. Ostati će povijesna uspomena na državnika Franju Tuđmana. Njegova je politička zasluga što je Hrvatska ponovno nakon 925. godine postala samostalna država. $S$ političkom sposobnošću $i$ vojnom nadarenošću Predsjednik Tuđman dosegao je taj cilj.

Dr. Hanning ${ }^{51}$

... Mađarska je uvijek s najvećim poštovanjem promatrala državnu djelatnost predsjednika dr. Franje Tuđmana, pa će $i$ u budućnosti na Hrvatsku gledati kao na svog strateškog partnera. Mađarskom je u interesu da Hrvatska bude u mogućnosti da se u najkraćem mogućem roku pridruži europskim integracijama.

Tibor Peto 52

... Duboko me ožalostila vijest o iznenadnoj smrti predsjednika Hrvatske $i$ vašeg voljenog otaca gospodina Franju Tuđmana. Njegova smrt doista je veliki gubitak ne samo za hrvatski narod, nego i za cijeli svijet. Duboko žalimo zbog odlaska lidera $s$ vizijom $i$ istaknutog zagovornika mira na Balkanu ...

Senkal Atasagun 53

U trenutku tužnog saznanja da nas je Predsjednik Tuđman napustio molim Vas da primite moje duboke izraze sućuti. Hrvatska nacija izgubila je jednog od svojih najvećih ljudi, jednog vrijednog čovjeka koji je cijeli svoj život posvetio dobrobiti Hrvatske i njenog naroda...

Sergio Mura ${ }^{54}$

50 Jacques DEWATRE, direktor francuske izvještajne službe DGSE.

51 Dr. Hanning, predsjednik njemačke izvještajne službe BND.

52 Tibor Peto, direktor mađarske izvještajne službe

53 Senkal Atasagun, direktor turske izvještajne službe MIT.

54 Sergio Mura, direktor operative talijanske izvještajne službe SISMI. 
... Iskreno izražavam sućut u povodu smrti utemeljitelja suvremene Hrvatske, Predsjednika Franje Tuđmana. Hrvatski narod je pretrpio težak gubitak - Predsjednik F. Tuđman je puno napravio za uspostavu $i$ procvat nezavisne hrvatske države. Pamtimo i cijenimo njegove napore prema razvitku prijateljskih odnosa između Hrvatske i Rusije.

V. Trubnikov55

Prigodom prelaska na - još jednu - etapu vaše svestrane karijere, želim vam zahvaliti na visokim profesionalnim standardima, osobnoj ljubaznosti i zadovoljstvu koje ste dosljedno pokazivali tijekom razdoblja naše bliske suradnje. Uvijek me se dojmilo da te iste kvalitete obilježavaju i vaš odnos s Vašim suradnicima - koji su to očito vrlo cijenili. Od vas sam naučio više praktičnih lekcija o tome kako biti dobar menadžer nego iz priručnika na policama Harvard Business School...

Stuart Brooks ${ }^{56}$

Dihotomija ne-javnih ocjena i pohvala prošlosti od stranaca, nasuprot javnoga političkoga progona aktera te prošlosti na domaćoj sceni, nije urednicima i suradnicima NSF-a mogla nametnuti moralne dvojbe ni političke dileme zbog nametanja krivnje za "dvostruke politike" 1990-ih. Štoviše, istina je obvezivana na odgovor, a časopis je bio mjesto za argumentirano dokazivanje.

Bez obzira koliko bio skučen prostor javnoga djelovanja $\mathbf{N S F}$ je postao i ostao prostor za analize i procjene tada važeće paradigme nacionalne sigurnosti i regionalnih integracija. Ono što nismo morali istraživati bile su medijske objede, političke krivotvorine i neutemeljene haške optužnice politike 1990-ih jer smo bili neposredni sudionici i svjedoci toga vremena, $s$ uvidom $u$ istinu $i$ objektivne informacije kao odgovorni djelatnici sustava nacionalne sigurnosti. 


\section{Odgovor na „teoriju i praksu“ programiranog kaosa}

U prvih 19 godišta $^{57}$ na preko 8000 tisuća stranica časopisa NSF, objavljeno je 257 radova od 141 autora. 58 Od 257 radova 148 objavljeno je na engleskom a 108 na hrvatskome jeziku. Prema vrsti priloga 114 je znanstvenih članaka, 39 studija, 20 dokumentacijske građe, 24 prikaza i recenzija, te 60 raznih tekstova (uredničkih proslova, in memoriam, preglednih prikaza konferencija i drugo). Od 141 autora 50\% je iz Hrvatske, a ostali su iz 25 različitih zemalja. Unatoč nepovoljnim okolnostima, medijskog blaćenja i političkog klevetanja urednika i suradnika, te bez financijske potpore, NSF je već po formalnim pokazateljima ostvarivao svoju viziju radi koje je pokrenut. No, od formalnih pokazatelja, daleko je važniji sadržaj objavljenih radova i utjecaj koji je imao i koji ima u znanstvenoj i stručnoj javnosti.

Nakon dvadeset godina izlaženja časopisa NSF moguće je prepoznati nekoliko područja i tematskih cjelina o kojima su pisali autori u tom razdoblju. Političke teme i sadržaje priloga određivale su vanjske okolnosti: strategija zapadnobalkanskih integracija, politička praksa kriminalizacije Domovinskoga rata i hrvatske politike prema Bosni i Hercegovini. Te su vanjske okolnosti, političkih i povijesnih stranputica, presudno utjecale i na uređivačku politiku časopisa u razdoblju do oslobađajuće presude generalima Gotovini i Markaču (2012.). Za uređivačku politiku to je bilo razdoblje sukoba $\mathrm{s}$ političkim obmanama i proizvodnjom kaosa.

Vanjske okolnosti i politika detuđmanizacije postupno su gubili na političkoj snazi i utjecaju nakon prijama Hrvatske u članstvo NATO-a (2009.), a pogotovo nakon što je Hrvatska postala punopravna članica EU (2013.). Političke tenzije i medijski obračuni izgubili su na snazi ali nisu nestali, no časopis se mogao fokusirati na aktualne prijetnje europskoj sigurnosti. Za uređivačku politiku počinje razdoblje istraživanja i planiranja europske kritičke infrastrukture.

57 Nisu uključeni podaci za 20 svezak NSF, tj. 2019. godinu.

58 Svi kvantitativni pokazatelji o produkciji NSF-a preuzeti su iz analize Đilda Pečarić, Miroslav Tuđman: Journal National Security and the Future: Bibliometric analysis in perod from 2000 to 2018. National Security and the Future $20(2-3) 2019$. 


\section{Vrijeme obmana i proizvodnje kaosa}

Bibliometrijska analiza objavljenih radova u NSF-u formira klastere, odnosno ukazuje na tematska područja s kojima su se autori najčešće bavili. Ključne su točke u tim klasterima: izvještajna djelatnost - sigurnost, BiH - Hrvatska, BiH Daytonski sporazum, Medački džep - politika, informacije izvjesnice, itd. No, ako zanemarimo vremenski slijed odjavljivanja radova, već dvadesetogodišnju produkciju časopisa želimo prikazati sa stajališta znanstvene metodologije onda možemo potvrditi da su sustavno objavljivani a) dokumentacijska građa relevantna za procjenu sukobljenih strategija i politika, b) studije slučajeva koje su bile predmetom kriminalizacije Domovinskoga rata i haških optužnica, c) djelatnost izvještajnih službi, te d) teorijske osnove i prikazi specijalnih operacija i informacijskoga ratovanja. Drugim riječima, NSF je svo vrijeme objavljivao javnosti nedostupne dokumente, analize i studije slučajeva, te teorijska tumačenja izvještajne prakse.

Za ilustraciju ovakve kategorizacije radova objavljenih u NSFa, potrebno je navesti nekoliko primjera. Nije nam namjera da budemo iscrpni, već smatramo da su u razdoblju „proizvodnje obmana i kaosa“ bili podjednako važni i objavljeni dokumenti kao i studije slučajeva. Teorijske rasprave uvijek dolaze post festum. Budući da su u turbulentnim političkim vremenima dokazi i analize događaja u pravilu „politički nekorektni“ za aktualnu vlast, to ne treba čuditi što službena politika financiranja znanstvenih časopisa nije bila voljna financirati NSF.

\subsection{Dokazima protiv krivotvorina}

NSF prvi je javnosti omogućio uvid u faksimile pet zapisnika sastanaka (od šest susreta) predsjednika republika i predsjednika predsjedništava republika SFRJ koji su se održali od ožujka do lipnja 1991., te faksimil zapisnika sastanka predsjednika SIV-a Ante Markovića sa rukovodstvom Republike Slovenije i Republike Hrvatske od 19. lipnja 1991. /NSF 3-4 (14) 2013; 1 (15) 2014; 2-3 (15) 2014;/. Svi su ti razgovori vođeni u dramatičnim okolnostima ustavno-pravne krize 1991. koja je dovela do raspada socijalističke Jugoslavije. Ovi izvorni dokumenti zorni su dokaz da su predsjednici Hrvatske i Slovenije, dr. Franjo Tuđman i Milan Kučan, zagovarali preustroj SFRJ u zajednicu suverenih država, odnosno mirni razlaz republika putem referenduma. Roman Domović u uvodnoj studiji: Stajališta 
predsjednika republika i predsjednika predsjedništava republika o ustavno-pravnoj krizi SFRJ na pregovorima od ožujka do lipnja 1991. / NSF 3- 4(14)2013,, str. 9-101/ dao je pregled $\mathrm{i}$ iscrpnu analizu stajališta što su ih predsjednici republika zagovarali. Analiza R. Domovića također dokazuje neodrživost nekih mitova koji još uvijek opterećuju hrvatsku političku stvarnost (NSF 3- 4(14)2013, st. 9-10.).

Izjava Radenka Radojčića objavljena u NSF 3-4 (10) 2009 (str. 49-222) jedan je od najposjećenijih dokumenata na portalu časopisa. Radenko Radojčić kao djelatnik u Stručnim službama Centralnog komiteta Saveza komunista Hrvatske (CK SKH) bio je suradnik vojnih i civilnih službi sigurnosti SFRJ, vođen pod pseudonimom "Ljudevit". Od 1990. godine bio je jedan od glavnih operativaca Uprave bezbednosti JNA (kolokvijalno poznate kao KOS) u operacijama "Labrador“ i informativno propagandnom odjelu „Opera“ formiranom u Beogradu 1991. Uhićen je i suđeno mu je u Zagrebu 1994. godine. NSF je objavio njegovu izjavu koju je dao u ožujku i travnju 1994. godine djelatnicima Službe za zaštitu ustavnog poretka MUP-a Republike Hrvatske. Izjava je bila važno svjedočanstvo o organizaciji, metodama, ciljevima i agenturi specijalnih operacija koje je vodila JNA protiv Hrvatske.

Autentični transkripti sjednice Predsjedništva BiH (od 21.6.1991. do 25.12.1994.) promijenili su medijsku sliku događaja o ciljevima sukobljenih strana u $\mathrm{BiH}$. NSF je objavio te transkripte u sedam svezaka /NSF 1-4 (7) 2006; 1 -4 (8) 2007/. Publicirani su oni dokumenti iz kojih se vide razvoj i promjene političke misli bosanskih Muslimana te (ne)principijelne koalicije unutar Predsjedništva $\mathrm{RBiH}$, a što je presudno utjecalo na proces odlučivanja i odluke koje je Predsjedništvo donosilo. Tomo Šimić je u opsežnoj studiji „Dokumenti Predsjedništva Bosne i Hercegovine 1991. 1994." dao analizu političkih ciljeva i stavova Alije Izetbegovića kao i sukoba unutar samog Predsjedništva /NSF 1-2 (7) 2006, str. 9-225/. Transkripti Predsjedništva $\mathrm{BiH}$ izazvali su veliku medijsku pozornost u $\mathrm{BiH}$, a postali su nezaobilazna građa povjesničarima i istraživačima rata i ratova u $\mathrm{BiH}$.

Brijunski transkript „sastanka predsjednika Republike Hrvatske dr. Franje Tuđmana s vojnim dužnosnicima“ održanog 31. srpnja 1995. na Brijunima bio je jedan od ključnih dokaza protiv generala Gotovine i Markača o ciljevima udruženog zločinačkog pothvata. U NSF-u objavljen je zapisnik tog sastanka /NSF 1 (11) 2010., str. 63-101/ ali i iscrpna analiza admirala Davora Domazeta Loše tog transkripta /NSF 1 (11) 2010., str. 11-44/ koji je i sam bio 
sudionik inkriminiranog sastanka. Analiza završava pitanjem: „Kamo to ide svijet na početku 21. stoljeća, ako se onaj tko se branio i pobijedio u ratu, medijskim i inim pričinama želi proglasiti agresorom na vlastiti teritorij, a njegovo stradanje i žrtva zločinom?". Nakon niza godina suđenja generali Gotovina i Markač oslobođeni su 2012. svih optužbi. Generali ni ne bi završili u Haagu da S. Mesić nije sporne transkripte selektivno dostavljao haškom Tužiteljstvu, $s$ jedinom namjerom da se optuži hrvatska politika i njezino vodstvo. No, i nakon oslobađajuće presude generalima A. Gotovini i M. Markaču, Mesić će ponoviti: „Ni danas mi nije žao što sam otvorio arhiv i podijelio Tuđmanove transkripte“.59

\subsection{Istinom protiv optužnica}

\section{Primjer prvi: Medački džep}

Haško Tužiteljstvo podiglo je optužnicu (17. rujna 2002.) protiv generala zbora Janka Bobetka, načelnika Glavnog stožera Hrvatske vojske (1992.-1995.) Optužnica ga je teretila da je za vrijeme vojne operacije u Medačkom džepu (od 9. rujna do 17. rujna 1993.) „planirao, poticao, naređivao, počinio ili na druge načine pomagao ... progone srpskih civila u Medačkom džepu na rasnoj, političkoj ili vjerskoj osnovi“. Medački džep je u hrvatskoj javnosti, "saturiranoj" samo jednom vrstom podataka, postao sinonim za HRVATSKI ZLOČIN, te je sve vezano uz tu akciju dobilo odbojno i negativno značenje. Optužnica je bila pokušaj da se oslobodilačka operacija Medački džep prikaže kao prijelomna točka na kojoj je nedvosmisleno dokazana hrvatska krivnja za zločin i etničko čišćenje te dokaže jednakost u zločinima Hrvata i Srba. Hrvatska je nakon objavljivanja optužnice za Medački džep u medijima postala krivac i za raspad Jugoslavije i "građanski rat".

General Bobetko poručio je da u Haag neće ići dok je živ, i da ga iz kuće mogu iznijeti samo mrtva. On se i u suton svojega života, u 83 godini, morao boriti za istinu i pravdu protiv optužbi da je pripadnik zločinačke organizacije i zločinačkog pothvata. Bez potpore tada aktualne državne politike. U tim kritičnim danima, u jesen 2002., predsjednik Republike Mesić izjednačio je generala Bobetka i Miloševića: "General je ... optužen za sasvim konkretne zločine koji su se nedvojbeno

59 Jutarnji list. http://www.jutarnji.hr/brijunski-transkript-ne-moze-bitinikakav-dokaz-da-je-hrvatska-izvrsila-genocid--/1173890/ (pristupljeno 23.3.2014.) 
dogodili ... To je kriterij na osnovi kojega se trenutno u Haagu sudi Slobodanu Miloševiću".

Haška je optužnica 2002. medijski nametnuta kao općeprihvaćena činjenica, sa svim posljedicama koja ona ima za hrvatsku državu, vojsku i narod. Ta haška povijesna „istina“, skoro dogma, ostala je bez temeljitog istraživanja s hrvatske strane. Haška je optužnica iskonstruirana na dokumentima, dokazima i svjedočenjima pripadnika Kanadskog bataljuna UNPROFOR-a koji je u rujnu 1993. u Lici vodio (nepostojeću) bitku s hrvatskom vojskom i specijalnim snagama MUP-a, "jedinu bitku koju je Kanadska vojska vodila nakon Korejskog rata" i za to 2002. bila odlikovana visokim kanadskim priznanjem. Zanimanje kanadske javnosti za tu "bitku" bilo je očito jer su do 2003. u Kanadi objavljene čak tri knjige koje se bave tim događajem: Sean M. Maloney \& Jonn Llambias "Chances for peace" (Šanse za mir); Carol Off "The ghosts of Medak pocket, The story of Canada's secret war" (Duhovi Medačkog džepa, priča o kanadskom tajnom ratu) te Scotta Taylora i Briana Nolana "Tested mettle" (Iskušana odvažnost").

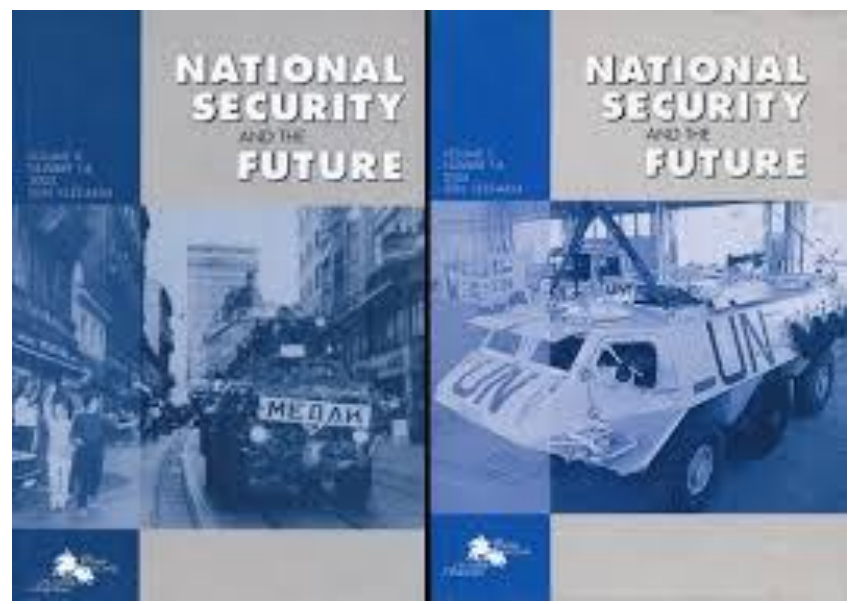

Miroslav Međimorec vrlo je pomno analizirao sve raspoložive izvore i dokaze (kanadske, srpske i hrvatske), izvješća UNPROFOR-a i kanadsko-francusku ulogu, strani i domaći tisak o Medačkom džepu, izvješća vojnih promatrača, itd. Činjenica je da nije bilo „bitke“ hrvatskih snaga sa kanadskim bataljunom, niti 27-30 poginulih i preko stotinu ranjenih hrvatskih vojnika u tom sukobu, kako tvrde Kanađani. Ni u UN-ovim dokumentima ne spominje se sukob CANBAT-a s Hrvatskom vojskom. Svjedočenje američkoga vojnog atašea potpukovnika Richarda C. Herricka o krivotvorenim podacima 
UNPROFOR-a za izvješće o Medačkom džepu, prisililo je i generala Cota na priznanje da su ga Kanađani obmanuli.

Analiza Miroslava Međimorca "Medački džep" na preko 500 stranica (NSF 1-4 (4) 2003.; NSF 1-4 (5) 2004.) iznosi niz podataka i dokaza ne samo o nepostojećoj bitci kanadskog bataljuna s $\mathrm{HV}$, nego i o neutemeljenosti optužnice protiv generala Janka Bobetka. U vrijeme objavljivanja studije M. Međimorca ona je bila jedini cjeloviti i objektivni odgovor na optužnicu generala J. Bobetka i obranu istine o Medačkom džepu.

General Janko Bobetko umro je 29. travnja 2003., kao haški optuženik. Dva mjeseca kasnije, 24. lipnja 2003., Raspravno vijeće haškoga Tribunala donijelo je odluku kojom je obustavilo postupak protiv generala Bobetka. Tek će 18. rujna 2015., dobiti zasluženo priznanje kada je po njemu nazvan Centar za obrambene $i$ strateške studije „Janko Bobetko"60 u sklopu Hrvatskog vojnog učilišta „Dr. Franjo Tuđman“. 61

Primjer drugi: Izvršio sam zapovijed: odveo sam u smrt 900 Hrvata

Bleiburg i križni put povijesni su događaji i činjenice o kojima se nije smjelo ni javno govori a ni pisati sve do 1990-te godine. Kada je šestorka dobila izbore 2000. godine odmah je ukinula pokroviteljstvo Hrvatskoga sabora nad komemoracijom na bleiburškom polju. I danas se mentalni komunisti protive istini o komunističkim zločinima počinjenim neposredno nakon završetka drugog svjetskog rata, jer je to po njima „revizija povijesti“. Studija M. Međimorca Izvršio sam zapovijed: Odveo sam u smrt 900 Hrvata (NSF 4 (9) 2008.), bavi se samo jednim fragmentom onoga što se zbivalo na Bleiburgu, ali i 2008. godine bila je neprihvatljiva „revizija povijesti“, jer je bila posredni dokaz da nije bilo bitne razlike u ponašanju JNA prema Hrvatima i 1945. i 1991.-1995. godine.

Studija je nastala na osnovi dviju izjava pod prisegom poručnika britanskog topništva Bernarda O'Sullivana u kojima osvjetljava uloga u izručenju 900 Hrvata koji su se u svibnju

60 Predsjednica RH i vrhovna zapovjednica OS RH Kolinda Grabar Kitarović, potpredsjednik Vlade i ministar obrane RH Damir Krstičević, načelnik Glavnog stožera OS RH general zbora Mirko Šundov u prisustvu obitelji Šušak, Bobetko i Zadro svečano su imenovali četiri dvorane u Ministarstvu obrane i Oružanih snaga, koje od 13. siječnja 2017. godine nose imena ratnog ministra obrane Gojka Šuška, stožernog generala Janka Bobetka, stožernog generala Zvonimira Červenka i generalbojnika Blage Zadre

61 Vlada Zorana Milanovića donijela je 15. rujna 2015. godine odluku da se HVU nazove po prvom hrvatskom predsjedniku. 
1945. predali britanskoj vojsci. U dvije izjave date pod prisegom poručnik britanskog topništva Bernarda O'Sullivana objašnjava svoju ulogu u izručenju devet stotina pripadnika OS NDH koji su se predali britanskoj vojsci, a ona ih je izručila Jugoslavenskoj armiji. Izjave pod prisegom O'Sullivana prvi puta su objavljene i prevedene na hrvatski jezik.

U studiji su objašnjene opće vojne i političke okolnosti na kraju Drugog svjetskog rata, bačeno svjetlo na britansku odluku o čišćenju palube, izručenju, suradnji Britanaca i Jugoslavenske vojske, o obmanama kojima su se Britanci koristili, moralnim dvojbama britanskih časnika u svezi s izručenjima, izručenju tzv. O'Sullivanove skupine, pokušaju razumijevanja što se s ratnim zarobljenicima dogodilo nakon izručenja i ukazano je na neke kaznenopravne aspekte zločina. Studija je dopunjena obiljem priloga, savezničkim i jugoslavenskim dokumentima, te bibliografijom. Izjave Bernarda O'Sullivana su do sada bile nepoznate hrvatskim povjesničarima i široj javnosti i mogu pomoći boljem razumijevanju bleiburških i poslijebleiburških događaja. ${ }^{62}$

Primjer treći: "Suci. Slobodan Praljak nije ratni zločinac!" Mjesec dana prije zatvaranja MKSJ izrečena je 29. studenoga 2017. zadnja haška presuda i to šestorici Hrvata u predmetu IT-04-74-T: dr. Jadranku Prliću, Bruni Stojiću, generalu Slobodanu Praljku, generalu Milivoju Petkoviću, Valentinu Ćoriću i Berislavu Pušiću. Nakon 24 godine MKSJ završava svoj mandat, ali bez presuda i osuda za rat i agresiju na Hrvatsku i BiH. Takav ishod implicira
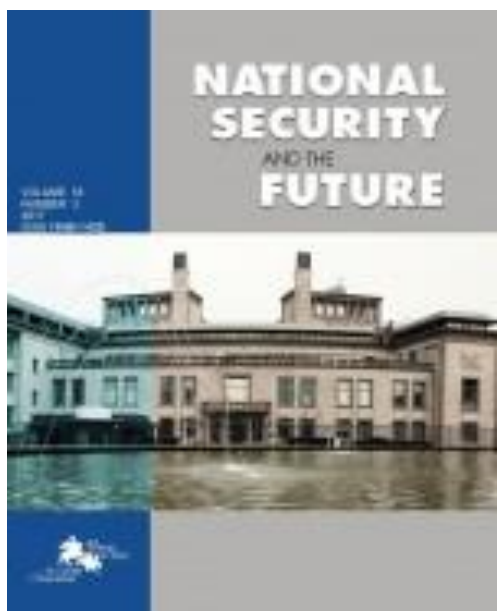
političku poruku da JNA nije izvršila agresiju na Hrvatsku i $\mathrm{BiH}$, Srbija nije agresor na BiH, a da je Hrvatska u ratovima tijekom raspada Jugoslavije jedina odgovorna za međunarodni sukob i to u $\mathrm{BiH}$.

General Slobodan Praljak - dosljedan u svojoj etičkoj beskompromisnosti, $\quad \mathrm{s}$ prezirom je odbacio nepravednu

62 Citiran je sažetak studije, Miroslav Međimorec: Izvršio sam zapovijed: odveo sam u smrt 900 Hrvata. NSF 4 (9) 2008., str. 97. 
presudu - kojom su on i ostala petorica - osuđeni za zločine koje nisu zapovjedili, koje nisu mogli spriječiti i za koje nisu znali, te si je u sudnici, pred kamerama koje su prenosile čitanje presude, oduzeo život.

Cijeli broj NSF-a posvećen je In memoriam generalu Slobodanu Praljku (NSF 3 (18) 2017.). Tekstove su napisali M. Tuđman (S prezirom odbacujem vašu presudu!), Luka Mišetić (Did the Tribunal Find Franjo Tuđman Responsible for Ethnic Cleansing in Bosnia and Herzegovina?.), Michael G. Karnavas (Časni prkos generala Slobodana Praljka). Objavljeni su i dokumenti suda: Završne riječi obrane generala Slobodana Praljka, te Izdvojeno $i$ djelomično suprotno mišljenje predsjedavajućeg vijeća: Kontekst predsjednika Raspravnoga vijeća, suca Claude Antonettiija.

Činjenica je da je sudac Antonetti ostao u manjini te su suci preglasavanjem (2:1) donijeli odluku o postojanju „zajedničkog zločinačkog pothvata“. Odvjetnici obrane pak svjedoče da je „dio mračne ostavštine MKSJ-a... školski primjer kako ne treba voditi predmet, kako ne treba birati sudsko vijeće, kako ne treba voditi sudsku raspravu, kako ne treba analizirati dokazni materijal, kako ne treba pisati presudu .... /to je/ bila parodija, šarada, teatar apsurda zamaskiran suđenjem".

Svjesni smo da broj NSF-a posvećen Slobodanu Praljku i presudi ostaloj petorici Hrvata ne može promijeniti presudu ali je inicijalni napor i nagovor koji će neminovno pokrenuti lanac istraga, istraživanja i preispitivanja te da će presuda izrečena 29. studenoga 2017 . ostati otvorena sve dok se ne utvrdi istina i donese presuda koja će odgovarati povijesnim činjenicama.

\subsection{Teorija i praksa izvještajne djelatnosti i informacijskog ratovanja}

Uredništvo NSF-a organiziralo je u Dubrovniku (27-28 listopada 2000. godine) okrugli stol na temu „Izvještajna djelatnost i nacionalna sigurnost na početku 21. stoljeća“. U raspravi su sudjelovali članovi uredništvo te pozvani gosti: dr. prof. dr. Wilhelm Agrell, general Todor Boyadjiev, prof. dr. Krešimir Ćosić, prof. dr. Stevan Dedijer, Duško Doder, admiral Davor Domazet-Lošo, veleposlanik Victor Jackovich, Richard Kerr, admiral Pierre Lacoste, prof. dr. Jan Leijonhielm, general N. Leonov, general Leonid Shebarshin, Douglas Smith, Richard Stolz, prof. dr. Miroslav Tuđman i Markus Wolf. Na četiri panela iznijeta su stajališta o ključnim 
temama s kojima su suočene izvještajne službe na početku 21. stoljeća:

(1) Izvještajne procjenjuje i promjene u Europi na kraju 20. stoljeća,

(2) Uloga izvještajnih službi u rješavanju sukoba i ratovi u jugoistočnoj Europi,

(3) Predmet i metode izvještajnih agencija na početak 21. stoljeća: mogućnosti i ograničenja,

(4) Etika i pravne norme u izvještajnoj djelatnosti i nacionalnoj sigurnosti (NSF 3-4 (1) 2000., str. 11-91).

Rasprava na ovom okruglom stolu bile su sažetak spoznaja i znanja istaknutih stručnjaka i znanstvenika o ključnim problemima i zadaćama izvještajne djelatnosti na početku trećega milenija, ali isto tako bio je to i dogovor o željenom programu uređivačke politike časopisa. Da je uredništvo nastojalo ostvariti postavljene ciljeve može se zaključiti iz pregleda objavljenih radova.

Tranzicija izvještajne djelatnosti te uloga i zadaće izvještajnih službi bili su predmetom analize i prikaza u nizu zemalja. Ovom prigodom nije moguće dati ni kratki prikaz uloge nacionalnih izvještajnih službi, ali već uvidom u naslove radova moguće je zaključiti o kojim se službama pisalo i s kojeg stajališta.

Stevan Dedijer piše o izvještajnom sustavu Dubrovačke Republike kao relevantnom modelu za 21 stoljeće (Ragusa Intelligence \& Security (RIS) - A Model for the 21st Century!?; NSF 3-4 (1) 2000.). Grozdan Cvetkovski analizira povijest izvještajne djelatnosti u Makedoniji i formiranje makedonske službe (Intelligence in Transition - The Case of Republic of Macedonia; NSF 2 (1) 2000.), a direktor SOVA-e (1993.1999.) Drago Ferš daje prikaz transformacije slovenske službe u izvještajnu agenciju (From Security and Intelligence Service to Slovene Intelligence and Security Agency; NSF 12 (3) 2002.). Povijest i budućnost grčke izvještajne službe analizira John M. Nomikos (Greek Intelligence Service (NISEYP): Past, Present and Future; NSF 1-2 (9) 2008.). Andrew $\mathrm{N}$. Liaropoulos također analizira institucionalne izazove $\mathrm{s}$ kojima se suočava grčka sigurnosna politika i zagovara mehanizme za učinkovitiju politiku sigurnosti i upravljanja krizama (The Institutional Dimension of Greek Security Policy: Is there a need for a National Security Council?, NSF 3(9) 2008.). 
Gordan Akrap rekonstruira odnos komunističke partije (KPJ, SKJ) i represivnoga aparata od OZNA-e, UDB-e do SDB-a (Mač $i$ štit u rikama partije - Represivni sustav u funkciji oblikovanja korpusa javnoga znanja; NSF 4 (11) 2010.). Gordan Akrap je na osnovu arhivske građe također prikazao suradnju izvještajnih službi DDR-a i SFRJ (Suradnja izvještajno-sigurnosnih sustava DDR-a i SFRJ; NSF 1-2 (12) 2011.). Jordan Baev analizira američke izvještajne procjene o stanju u Jugoslaviji od 1948. do 1991. (US Intelligence Community Estimates on Yugoslavia (1948-1991); NSF 1 (1) 2000.).

Povijest nastanka i djelovanja HIS-a (Hrvatske izvještajne službe) napisao je Miroslav Tuđman (The First Five Years of the Croatian Intelligence Service: 1993-1998., NSF 2 (1) 2000.). A zajedno s Gordanom Akrapom analizira formiranje hrvatske izvještajne zajednice prema demokratskim načelima (From totalitarian to democratic intelligence community case of Croatia (1990-2014); NSF 2 (14) 2013.). Ivo Lučić prikazuje početke i te pravne okvire za djelovanje sigurnosnih i izvještajnih službi u Bosni i Hercegovini (Security and Intelligence Services in Bosnia and Herzegovina; NSF 2 (1) 2000.).

Stvaranjem novoga europskog poretka pod konac 20. stoljeća i najrazvijenije zemlje morale su redefinirati zadaće svojih izvještajnih službi. Wilhelm Agrell na primjeru Švedske tumači ulogu izvještajne djelatnosti u vremenu tranzicije (Intelligence in an Age of Transition - The Case of Sweden; NSF 2 (1) 2000.). Laszlo Botz razmatra promjene u zadaćama i ulozi mađarske vojne izvještajne službe nakon ulaska Mađarske u NATO (New Tasks of the Hungarian Military Intelligence Office after NATO Accession Hungarian Military Intelligence at the Turn of the Century; NSF 2 (1) 2000.). Victor Jackovich raspravlja o ulozi izvještajne djelatnosti i nacionalne sigurnosti u novome okruženju (Intelligence and National Security: Adjusting to a Post-Cold War Environment; NSF 3-4 (1) 2000.), a Jan Leijonhielm o potrebi fokusiranja na gospodarske izvjesnice (Need for Economic Intelligence; NSF 3-4 (1) 2000.). Leonid Shebarshin kritički tumači odnos kreatora politika prema izvjesnicama i izvještajnoj djelatnosti (Intelligence Information and Policy Makers; NSF 3-4 (1) 2000.). Helene L. Boatner piše o razmjeni izvjesnica i pravilima njihove uporabe u međunarodnim organizacijama (Sharing and Using Intelligence in International Organizations: Some Guidelines; NSF 1 (1) 2000.). Thomas Patrick Melady i Sean Hilscher ukazuju na potrebu međunarodne suradnje na zajedničkim 
izvještajnim procjenama (Cooperative Intelligence) u borbi protiv terorizma i globalnih prijetnji (Intelligence: Worldwide Cooperation; NSF 3 (9) 2008.). Siniša Košutić ukazuje da su sustavi ranoga upozoravanja pretpostavka izbjegavanja iznenađenja kako na korporativnoj tako i na nacionalnoj razini (Sustavi ranog upozoravanja; NSF 3 (13) 2012.). Duje Ančić procjenjuje učinkovitost Europske unije i NATO-a o strateškom komuniciranju, tj. javnoj diplomaciji i odnosima s javnošću (Strateško komuniciranje u Europskoj uniji $i$ Sjevernoatlanskom savezu; NSF 2-3 (16) 2015.).

Leonid V. Shebarshin pak procjenjuje da će svijet i u 21. stoljeću biti bremenit sukobima te da će uloga izvještajnih službi i važnost izvjesnica dobivati još više na značenju (Intelligence in the Twenty-First Century; NSF 1 (1) 2000.). Gordan Akrap i Miroslav Tuđman ukazuju da je jugoistok Europe bojišnica na kojoj se vodi informacijski rat (Southeaster Europe (SEE) - Intelligence and Security Services Battlefield?; NSF 3 (17) 2016.).

Jugoistok Europe bio je poligon je za informacijske operacije i informacijsko ratovanje na kojem se testiraju metode i tehnike medijskih operacija koncem 20. i početkom 21. stoljeća. M. Tuđman daje prikaz medijskih i informacijskih operacija SFOR-a u BiH 1990-ih godina, na čijim su se iskustvima potom pisali priručnici za informacijsko ratovanje. (Informacijske operacije $i$ mediji ili kako osigurati informacijsku superiornost; NSF 3-4 (10) 2009.). Roman Domović bavi se raščlambom medijskih operacija i informacijskim ratom u Hrvatskoj: Metodologija provođenja informacijskih operacija; NSF 2-3 (16) 2015.); Inverzija istine - metoda ostvarivanja dominacije u javnom informacijskom prostoru; NSF 2-3 (11) 2010.); Tehnike informacijskih operacija: Globusove karte o podjeli Bosne i Hercegovine; NSF 1 (14) 2013.).

Osim empirijskih i analitičkih istraživanja medijskih i informacijskih operacija niz je autora objavilo teorijske radove koji se bave informacijom kao oružjem. Preciznije, s razvojem globalne informacijske infrastrukture dolazi do dvije bitne promjene u filozofiji međunarodnih odnosa: prvo, uporaba „mekane moći“ dobiva prednost nad uporabom „tvrde sile“, odnosno javna diplomacija ima prioritet u odnosu na vojne operacije; drugo, informacija postaje jedan od četiri osnovna instrumenta nacionalne moći. $\mathrm{Na}$ tom tragu, M. Tuđman zaključuje da će u 21 stoljeću pogotovo male zemlje biti izložene sve većim rizicima jer meka moć napada kulturu, vrijednosti i politiku ciljane javnosti. Sigurnost i budućnost malih zemalja uvjetovana je zaštitom kulturnog identiteta i 
nacionalnih vrijednosti (Izvještajne službe i meka moć; NSF 1 (14) 2013.).

Gordan Akrap nudi kategorijalni aparat za analizu i razumijevanje učinkovitosti informacijskih strategija i operacija na oblikovanje javnoga znanja (Informacijske strategije i oblikovanje javnoga znanja; NSF 2 (10) 2009.). Slavko Barić proučava koncept asimetričnog ratovanja i njegov utjecaj na proces inovacija vojnih doktrina $u$ posthladnoratovskom razdoblju (Vojne strategije $i$ asimetrično ratovanje; NSF 4 (11) 2010.). Vilko Klasan smatra da je hijerarhija znanja presudna za vojno umijeće te da piramidu znanja treba „spojiti" sa zapovjednom hijerarhijom i upravljanjem na taktičkoj, operativnoj, strategijskoj razini (Upravljanje vojnim znanjem NSF 2 (10) 2009.).

Bosna i Hercegovina bila je u vrijeme raspada Jugoslavije žarište velikoga ratišta: informacijskog, političkog, vojnog i diplomatskog. Daytonski sporazumi zaustavili su rat, ali nisu donijeli mir i stabilnost u Bosni i Hercegovini. Politički obračuni u samoj $\mathrm{BiH}$ i diplomatski prijepori oko $\mathrm{BiH}$ traju i danas. NSF nije mogao ne baviti se tom temom. Ne samo zato što je pitanje regionalne sigurnosti u fokusu njegova interesa, nego i zato što su detuđmanizatori optuživali hrvatsku politiku za „podjelu Bosne“, a haško Tužiteljstvo gradilo optužnice na tim i takvim objedama. U NSF-u objavljeno je preko 20 znanstvenih radova koji obrađuju povijesne, političke, vojne, diplomatske odnose, i posljedice tih odnosa, u $\mathrm{BiH}$ i oko $\mathrm{BiH}$. Nužno je navesti naslove neke od tih radova kako bi se naznačio pristup, i ukazalo na napore koji su uloženi u istraživanje prošlosti i budućnosti $\mathrm{BiH}$.

Davor Domazet - Lošo analizira strateške pripreme JNA za agresiju na $\mathrm{BiH}$ i $\mathrm{RH}$, te transformaciju JNA $u$ instrument velikosrpske politike (How Aggression Against Croatia and Bosnia-Herzegovina Was Prepared or the Transformation of the JNA into a Serbian Imperial Force; NSF 1 (1) 2000.). Davor Marijan kritizira "historičare“ jer je jedini način za razumijevanje rata u $\mathrm{BiH}$ kroz činjenice a ne predrasude, koje su posebno oštre kod muslimansko-bošnjačkih autora (The War in Bosnia and Herzegovina or the Unacceptable Lightness of "Historicism"; NSF 1 (1) 2000.).

Božo Žepić analizira planove za uređenje $\mathrm{BiH}$, te dokazuje da međunarodna zajednica nema jasno i cjelovito rješenje jer nacionalno pitanje "gura pod tepih“ (Prijedlozi $i$ planovi međunarodne zajednice za Bosnu i Hercegovinu; NSF 3-4 (6) 2005.). Saša Mrduljaš analizira političko-idejne osnove Vance-Owenova plana, te razloge koji su doveli do 
radikalne promjene međunarodnog pristupa unutarnjem uređenju $\mathrm{BiH}$ (Prvi međunarodni pokušaj unitarizacije Bosne I Hercegovine: Vance-Owenov plan (2. siječnja 1993.); NSF 2 (10) 2009.). Gordana Iličić tumači ciljeve političkih elita u $\mathrm{BiH}$ : hrvatska je elita težila federalnoj državi s tri entiteta, srpska stvaranju „velike“ Srbije, bosanska politička elita želi stvoriti nacionalnu državu Bosnu (Hrvati u BiH 1991.-1995. godine: nacionalni sukobi i uloga međunarodne zajednice $u$ mirovnim procesima; NSF 3 (9) 2008.). Ivo Lučić bavi se porijeklom i evolucijom elita u Bosni i Hercegovini, te mogućnostima i učinkovitosti elita (Evolution and Condition of the Elites in Bosnia-Herzegovina - A Personal View; NSF 34 (6) 2005.).

Martin Raguž smatra da daytonska formula - jedna država, dva entiteta i tri konstitutivna naroda s potpuno asimetričnom ustavnom i pravnom strukturom - nije jamstvo za mir, stabilnost i opstanak BiH (Bosnia and Herzegovina - Five Years After Dayton; NSF 1-2 (2) 2001.). Gary Demsey smatra da je Daytonski sporazum kočnica ekonomskim i političkim reformama jer umjetno čuva okruženje vječne konfrontacije i političke nesigurnosti (Bosnia: The Making of a Potemkin State; NSF 1-2 (2) 2001.). Kenneth Allard također smatra da ciljevi Daytona nisu postignuti, te da je potrebno sazvati novu međunarodnu konferenciju radi osiguranja buduće stabilnosti Balkana i priprema za reintegraciju tih država u europsku zajednicu (Dayton II:Is it possible? Is it necessary?; NSF 1-2 (2) 2001.). Ivo Lučić opisuje genezu terorizma u $\mathrm{BiH}$, a najopasniji je islamski terorizam, tj. tisuće "mudžahedina" koji se u $\mathrm{BiH}$ bore za islam uz potporu muslimanske vlade (Bosnia and Herzegovina and Terrorism; NSF 3-4 (2) 2001.).

Paško Radica konstatira da je $\mathrm{BiH}$ nedovršena država te postavlja pitanje na kojim je osnovama moguće uspostaviti samoodrživu političku zajednicu (Bosna i Hercegovina Nedovršena država, podijeljeno društvo, i nemogućnost konstituiranja političke zajednice; NSF 3 (17) 2016.). Damirka Mihaljević analizira rezultate istraživanja agencije PULS koji ruše stereotipe o BiH kao podijeljenom društvu (Ima li i Bosna i Hercegovina priliku izgraditi zajednički sustava vrijednosti?; NSF 1 (11) 2010.). Mladen Ančić pokazuje da je obrana punoga naziva Bosne i Hercegovine u hrvatskoj političkoj i intelektualnoj eliti zapravo posljedica nesvjesnoga prihvaćanja „strategije slabih“ i da je dobila simbolično značenje očuvanja kakve takve nacionalne ravnopravnosti. (Što je Bosna bez Hercegovine? ; NSF 3-4 (6) 2005.). Božo Žepić raščlanjuje četiri modela ustavnoga uređenja $\mathrm{BiH}$, što 
in je 2003. godine predložio Centar za sigurnosne studije u Sarajevu (Četiri modela ustavnog preuređenja Bosne $i$ Hercegovine; NSF 1-2 (6) 2005.).

Radoslav Dodig daje pregled povijesti Hercegovine a vidi je kao moderno ustrojenu bh. regiju, prepoznatljivu kao jadransko-dalmatinsko zaleđe (Hercegovina ili esej o "zemlji na ćenaru"; NSF 3-4 (6) 2005.). Ivo Lučić polazi od činjenice da su Hercegovci zbog jakog nacionalnoga naboja kroz povijest uvijek bili protiv svake protuhrvatske politike, pa zato sve više jača ideja o Hercegovini kao republici ili europskoj regiji (Ima li Hercegovine? /Tko i zašto negira Hercegovinu i Hercegovce?/); NSF 3-4 (6) 2005.).

\section{Nacionalni interesi i europska kritička infrastruktura}

Tijekom proteklih dvadeset godina došlo je do promjene međunarodnoga položaja Hrvatske, što je bitno utjecalo i na unutarnje političke odnose. Hrvatska je primljena u punopravno članstvo NATO-a 2009. godine, a u EU sredinom 2013. godine. Odnos prema Domovinskome ratu hrvatske službene politike i provladinih medija počeo se mijenjati tek nakon punopravnoga članstva u tim organizacijama, te oslobađajućih presuda hrvatskim generalima u Haagu (2012.). Međutim, ostale su stare unutarnje podjele na političkoj sceni jer je lijeva politička opcija odbacila politiku pomirbe. HVO i Hrvati u BiH i dalje su politički diskreditirani i kriminalizirani kao pripadnici udruženog zločinačkog pothvata od protivnika federalizacije BiH i zagovornika bosanskoga unitarizma: „Svako spominjanje Trećeg entiteta, federalnih jedinica, federalizacije, je samo nastavak udruženog zločinačkog pothvata Tuđmanovog režima" (Bakir Izetbegović). Unatoč činjenici da je Europski parlament izglasao dvije rezolucije o BiH (veljača 2014., i u veljači 2017.) u kojima se ,ističe važnost načela federalizma i legitimnog predstavljanja kako bi se osigurao europski put Bosne i Hercegovine". ${ }^{63} \mathrm{BiH}$ je bila i ostala trajni problem regionalne sigurnosti kao „nedovršena država“ u kojoj dominira stanje zamrznutog sukoba.

Osim toga i takvog negativnoga nasljeđa iz 2000-tih godina, Hrvatska je bila suočena i s dugogodišnjim negativnim posljedicama globalne ekonomske krize (2008.), migrantskim

63 Rezolucije su jasna poruka da „Separatizam s jedne, a unitarizam, centralizam s druge strane, blokiraju $\mathrm{BiH}$ na putu prema EU, a u rezoluciji se ponavlja da federalizam može osigurati europsku budućnost BiH“" (Davor Stier, 6.2.2014.) 
tsunamijem (2015.), vlastitim velikim demografskim gubicima nakon ulaska Hrvatske u EU, itd. Hrvatska je morala naučiti da je izložena globalnim prijetnjama, koje se ne mogu riješiti i rješavati na nacionalnoj razini već odgovore treba tražiti zajedno s drugim članicama EU i NATO-a.

Izdavač NSF, Udruga sv. Jurja, bila je inicijator i uz Hybrid Warfare Research Institute (Zagreb), jedan o osnivača Zagreb Security Foruma. Od 2016. godine suorganizatori Zagreb Security Forum su Hrvatsko vojno učilište „Dr. Franjo Tuđman", Bar-Ilan University, Department of Political Studies, Ramat-Gan (Israel), International Intelligence History Association (Germany), Research Institute for European and American Studies (Greece), Ured za upravljanje $u$ hitnim situacijama (Grad Zagreb) te Adriatic Security Solutions d.o.o. (Zagreb). Zagreb Security Forum održava se svake godine pod visokim pokroviteljstvom predsjednice Republike Hrvatske, odnosno Vlade $\mathrm{RH}$.

Nakon pet godina iskustva možemo zaključiti da je Zagreb Security Forum (ZSF) postao respektabilan skup na kojem svake godine sudjeluje oko 30 stručnjaka i znanstvenika iz više od 20 zemalja. Posljednjih godina ZSF podupire i NATO Science for Peace and Security Programme.

Časopis National Security and the Future od 2017. godine objavljuje i radove koji su pripremljeni za ZSF. To je bio i razlogom zašto su u uredništvo uključeni organizatori ZSF-a: prof. dr. Shlomo Spiro (Bar Ilan University, Israel), prof. dr. John Nomikos (Research Institute for European and American Studies, Greece) i prof. dr. Iztok Podbregar (University of Maribor, Slovenia).

$U$ fokusu rasprava na ZSF-u je funkcioniranje nacionalnih kritičnih infrastruktura jer je to jedan od stupova obrane i na nacionalnoj razini i na razini međunarodnih organizacija. Razvoj i zaštita nacionalne kritičke infrastrukture (NKI) u suvremenom svijetu koji je fragmentiran po nizu kriterija, ipak ostaje zajedničko područje međunarodne suradnje jer je NKI pretpostavka održivog razvoja svakog društva i države. Zato je presudna suradnja u području: preventivne zaštite energetske infrastrukture; neizbježne zaštite vode radi održavanja života; planiranja modela mogućeg kriznog upravljanja NKI; otpora izazovima s kojima se infrastruktura nalazi ili će i se suočavati; te do suradnje u području hibridnih prijetnji. Rasprave na ZSF-u posebno su bile usredotočene na zaštitu od pomorskog terorizma, uporabu bespilotnih letjelica u terorističkim akcijama, te od prijetnji iz cyber svijeta. Cyber prostor je okosnica budućeg razvoja ali oni koji 
razmišljaju samo o tome kako se zaštititi od cyber prijetnji ostat će na repu razvojnih procesa i događaja. Preko 40 radova na ove teme objavljeni su u brojevima NSF 1-2 (17) 2016; NSF 1-2 (18) 2017; NSF 1-2 (19) 2018; NSF 1-2 (20) 2019.

\section{Umjesto zaključka: o odjeku i utjecaju NSF-a}

Nakon dvadeset godina izlaženja moramo potražiti odgovor i na pitanje kakav odjek i utjecaj ima časopis National Security and the Future u području nacionalne sigurnosti i izvještajne djelatnosti, odnosno u domaćoj i međunarodnoj javnosti. Kvantitativni podaci o broju objavljenih radova su dostupni: na preko 8.000 stranica objavljeno je 257 tekstova, koje potpisuje 134 različita autora tijekom 19 godina izlaženja časopisa. ${ }^{64} \mathrm{NSF}$ je dvojezičan časopis, usporedo se objavljuju članci na engleskom (148 članaka) i hrvatskom (108 članaka) jeziku. ${ }^{65}$

Kvantitativni podaci o autorima i autorstvu su također dostupni. Najviše autora je iz Hrvatske 50\%. Ostali autori dolaze iz 25 zemalja: 7,5\% iz Sjedinjenih Američkih Država; $5,2 \%$ iz Bosne i Hercegovine; 4,5\% iz Njemačke, itd. Najveći broj radova potpisuje samo jedan autor (88,6\%).

National Security and the Future dostupan je na vlastitom portalu (http://www.nsf-journal.hr/) ali i na portalu hrvatskih znanstvenih i stručnih časopisa HRČAK (https://hrcak.srce.hr/nsf). Suvremene tehnologije omogućavaju praćenje i uvid u evidenciju čitanosti svakoga objavljenog teksta. Međutim, dostupni podaci nisu kompletni jer je NSF na portalu HRČAK od 2007. godine, a za 170 članaka (20 brojeva časopisa) na stanici časopisa (www.nsfjournal.hr) nema dostupne evidencije o preuzimanju članaka. Unatoč tome bilo je daleko više preuzimanja tekstova sa stranice časopisa - 263.560 preuzimanja, dok je sa portala HRČAK bilo 184.778 preuzimanja. Ukupno je bilo 448.338 preuzimanja s obje stranice. Prema podacima Google Analytics preuzimanja su bila iz 131 zemlje (samo za http://nsf-journal.hr).

64 Nisu uključeni podaci za 2019. godinu. Objavljeno je 114 članaka, 39 studija slučajeva, 20 dokumenata, 24 recenzije publikacija, 60 tekstova različita sadržaja.

65 Svi kvantitativni podaci na koje se pozivamo u ovom radu su preuzeti iz članka Đilda Pečarić, Miroslav Tuđman: Časopis National Security and the Future: Bibliometrijska analiza u razdoblju od 2000. godine do 2018. godine, NSF 3(20) 2019. 
Kvantitativni pokazatelji mogu biti indikator odjeka časopisa, ali ne mogu poslužiti kao pokazatelji utjecaja časopisa. Uvriježena je praksa da se znanstveni časopisi i autori radova, pogotovo u "globalnim“ znanostima (a u daleko manjoj mjeri u humanističkim i društvenim znanostima) pozivaju na citiranost članaka, odnosno autora, kako bi istaknuli utjecaj koji ti autori imaju u znanstvenoj zajednici. Nemamo uvid u podatke o citiranosti autora koji su objavljivali u NSF-u, a niti podatke o citiranosti radova objavljenih u NSFu.

Citiranost autora koristi se kao argument o relevantnosti znanstvenih teorija, a (ko)citatna analiza autora za rekonstrukciju razvoja znanstvenih paradigmi. U području izvještajne djelatnosti i nacionalne sigurnosti samo se teorijskim radovima može pripisati takva zadaća. Strategijske procjene i analitičke izvjesnice (te dokazi i činjenice na kojima se temelje) projekcije su promjena koje će se dogoditi u bližoj budućnosti ako korisnici ili društvo kojem su namijenjeni poduzmu (ili ne poduzmu) potrebne aktivnosti. Drugim riječima, izvještajne procjene zastarijevaju nakon vremena na koje se procjene odnose.

Tekstovi koji su objavljeni u NSF-u, također, zastarijevaju s promjenom geostrateških i političkih prilika o kojima referiraju. Takvi tekstovi su aktualni dok nude interpretaciju ishoda postojeće politike, odnosno mogućih scenarija političkog i društvenog razvoja. Tekstovi NSF-a su relevantni u onoj mjeri u kojoj svojim argumentima i činjenicama i sami utječu na javnost i politiku. Je li NSF imao utjecaja na promjene političkih prilika u Hrvatskoj? Faktor utjecaja kvantitativne metode ne mogu mjeriti. Možemo samo naznačiti vrijednosnu prosudbu, ako podsjetimo na to što se promijenilo tijekom 20 godina na političkoj sceni.

Prvih petnaest godina časopisa NSF opisali smo kao vrijeme „obmane i kaosa“, u kojem je časopis objavljivao tekstove protiv kriminalizacije domovinskoga rata, neutemeljenih haških optužnica, protiv uključivanja Hrvatske u zapadnobalkanske asocijacije, i sl. Krunski svjedok optužbe koji je u Haagu lažno svjedočio o dvostrukoj politici predsjednika Tuđmana (jer je ovaj navodno dogovorio podjelu Bosne i Hercegovine s Miloševića u Karađorđevu 1991.) izabran je za predsjednika Republike 2000. godine. Pozicija predsjednika Republika Stjepanu Mesiću dala je moć da započne obračun sa svim "pripadnicima“ udruženog zločinačkog pothvata. Čak i oni iz SDP-a koji su govorili pozitivno o predsjedniku Tuđmanu bili su izloženi političkom 
linču. 66 Stjepan Mesić će i 2010. izjaviti "morat ćemo zabraniti HDZ" (Globus, veljača 2010.). Treći predsjednik Republike Ivo Josipović tek će ublažiti svoju retoriku ali neće u bitnome promijeniti svoje stavove u odnosu na svojega prethodnik. Josipović će u Sarajevu govoriti za rat u BiH „Kriv je konglomerat loših politika“, a u Knessetu će (2012.) reći „trebamo znati“ ustaška „zmija je sad oslabljena, ali je još uvijek tu".

Međutim, u Haagu su 16. studenog 2012. hrvatski generali oslobođeni. Izostala je osuda „Tuđmanova režima“, osuda „njegova projekta“ i njegovih „,deset mračnih, izgubljenih godina“. Istoga dana hrvatski generali euforično su dočekani na Trgu bana J. Jelačića u Zagrebu. Rijetko je kada središnji zagrebački Trg bio tako pun ljudi, emocija i ekstaze oduševljenja zbog oslobađanja od optužbe ne samo hrvatskih generala nego i najvišeg vojnog i političkog vodstva Hrvatske. ${ }^{67}$

Službena je politika suzdržano pozdravila oslobađajuću presudu. No, narednih godina kriminalizirati Domovinski rat nije više mogla ni jedna parlamentarna stranka. Svi oni koji su haške optužnice željeli pretočiti u kolektivnu krivnju hrvatske politike za „etničko čišćenje“ Srba u Hrvatskoj ili „podjelu

66 Prof. dr. Zdravko Tomac jedini je predstavnik tada vladajuće koalicije koji se odazvao pozivu da sudjeluje na simpoziju "Tuđmanizam i detuđmanizacija“" što ga organizirao HIP 7. prosinca 2002. godine. Njegov referat „Moji pogledi na ulogu dr. Tuđmana u donošenju sudbinskih odluka u razdoblju 1989.-1992." izazvao je burne reakcije. Zamjenik glavnog urednika Jutarnjeg lista Davor Butković, predsjednica kluba HNS-a, PGS-a i SBHS-a Vesna Pusić pokreću medijski i politički linč protiv Z. Tomca. Butković optužuje Z. Tomca da je „desničar ... te da prema svojim stavovima pripada hipovcima Miroslava Tuđmana“. Vesna Pusić traži od predsjednika Hrvatskog sabora Zlatka Tomčića pokretanje postupka za smjenu Z. Tomca $\mathrm{S}$ mjesta potpredsjednika Hrvatskog sabora i predsjednika Odbora za vanjsku politiku Hrvatskog sabora. V. Pusić tvrdi da Z. Tomac „rehabilitira i zagovara Tuđmanovu politiku prema Bosni i Hercegovini“ što je „u dijametralnoj suprotnosti s našim stavovima“ jer to je „točka oko koje vlada potpuna suglasnost današnje koalicije na vlasti ... u jednodušnoj osudi i osporavanju te /Tuđmanove/ politike“.

67 Istoga dana predsjednik RH Ivo Josipović pozvao je oslobođene generale i sve generale, ratne zapovjednike, u svoju rezidenciju na Pantovčak. Tako se po prvi puta nakon 1999. našlo 48 hrvatskih generala, ratnih zapovjednika, ponovo u svečanim odorama i ponovo u svečanoj dvorani u Uredu predsjednika Republike Hrvatske na Pantovčaku. S. Mesić je osudio takav postupak: "Ja nikada ne bih pozvao umirovljenje generale koji su pamfletom išli protiv sustava, a posebno još u uniformama da dođu na prijem". S. Mesić smatra da je primanjem umirovljenih generala u Uredu predsjednika aktualni predsjednik dezavuirao njegovu odluku o umirovljenju, a umirovljenim generalima dao legitimitet. 
Bosne“, za svoje objede više nisu mogli naći potporu izvan Hrvatske, jer su takve klevete nespojive s uvjetima što in je Hrvatska morala ispuniti da bi postala punopravna članica NATO-a 2009., članica EU 2013., a 2012. godine odbačena je i haška optužnica.

Razdoblje „obmane i kaosa“ završava bez isprika i odgovornosti za počinjene nepravde, degradacije, objede, izbacivanja iz sustava, izgubljene karijere - postupnom rehabilitacijom na simboličkoj razini,. Po prvom hrvatskom predsjedniku nazvano je Hrvatsko vojno učilište (2015.), nazvana je i zračna luka u Zagrebu (2016.). U glavnom gradu Hrvatske otkriven je spomenik prvom predsjedniku (2018.). General Damir Krstičević, koji je 2000. degradiran i umirovljen jer je „pamfletom rušio državu“, imenovan je potpredsjednikom Vlade RH i ministrom obrane 2016. godine. Poštivanje Domovinskoga rata, branitelja i pobjedničkog mentaliteta ponovo su se vratili u Hrvatsku vojsku.

Je li NSF utjecao na sve te promjene? Bilo bi pretenciozno davati časopisu i autorima objavljenih članaka preveliko značenje. Ali isto tako ne bi bilo korektno negirati doprinos časopisa tim promjenama. Na takav zaključak upućuju i biografije mladih neovisnih autora ali i onih autora koji su bili neposredni sudionici i svjedoci povijesnih zbivanja 1990-ih, te su dosljedno svjedočili istinu. U razdoblju „obmane i kaosa“ osim časopisa djelovao je i niz drugih autora, održavane su tribine, publicirane knjige koje u pravilu nisu imale državnu potporu. Medijska prešućivanja knjiga, promocija i tribina te političke diskvalifikacije u javnosti i za javnost homogenizirale su autore tih tekstova i zbivanja. Autori i tekstovi u NSF-u bili su sastavni dio hrvatske pripovijesti o nepoćudnim knjigama, - nepoželjnim ljudima o prešućenim događajima $\mathrm{i} o$ ustrojenom otporu u doba detuđmanizacije i kriminalizacije Domovinskoga rata.

U mjeri u kojoj će ondašnji i današnji čitatelji NSF-a prepoznati kritičku vjerodostojnost i objektivnost tekstova, u toj je mjeri i NSF pridonio političkim i društvenim promjenama. Nažalost, političke i povijesne promjene završile su bez isprike za političke stranputice i bez osude detuđmanizatora, te bez pravde za žrtve političkih obračuna 2000-ih. Za žrtve istina i pravda ne pobjeđuje, jer su istina i pravda tek mjerila kojima naknadno - po završetku priče - vrednujemo životne postupke i sudbine.

Nakon razdoblja "obmane i kaosa“ pred nama je novi ciklus izazova, prijetnji i kriza. Vrijednost procjena i scenarija o kojima autori u NSF-u pišu posljednjih pet godina tek čekaju 
svoju provjeru. To je početak novoga ciklusa kriza, prijetnji i stradanja kojima se još ne naziru konačna rješenja. Mir i blagostanje tek su trajna težnja ali nikada nisu bili zajamčeni ni pojedincima, ni narodima, ni državama. Časopis National Security and the Future mora se i u buduće baviti tim i takvim svijetom jer težimo da bude bolji, ali moramo biti pripravni i na najgore scenarije. Jer takav je svijet u kojem živimo:

„Najbolji, najsavršeniji što može biti, jer drugoga nema. $S$ velebnim moralnim, znanstvenim i kulturnim dostignućima svega čovječanstva. Ali, i najnesretniji i najopakiji što može biti jer gorega je $i$ teško zamisliti, sa svim zlosiljem $i$ opačinama što ih proživljava sveukupno ljudstvo, uzrokovanim ne samo trajnom prisutnošću barbarskog divljaštva, nego i rastrojstvenom izopačenošću najsuvremenijih civilizacija ovoga svijeta. Razumije se, $i$ naša je Hrvatska sastavni dio tog i takvog najplemenitijeg, ali i najiskrivljenijeg svijeta."

Dr. Franjo Tuđman (23. veljače 1997.) 